Published in "Marine Geology 352: 89-110, 2014"

which should be cited to refer to this work.

\title{
Carbonate mounds: From paradox to World Heritage
}

\author{
J.P. Henriet ${ }^{\text {a,* }}$, N. Hamoumi ${ }^{\text {b }}$, A.C. Da Silva ${ }^{\text {c }}$, A. Foubert ${ }^{\text {d }}$, B.W. Lauridsen ${ }^{\text {e }}$, A. Rüggeberg ${ }^{\text {a,d,f }}$, D. Van Rooij ${ }^{\text {a }}$

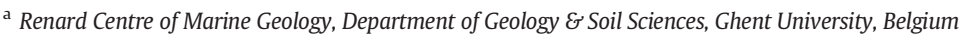 \\ b Faculty of Sciences, Mohammed V University-Agdal, Rabat, Morocco \\ c Sedimentary Petrology, Liège University, Belgium \\ d Department of Geosciences, University of Fribourg, Switzerland \\ e Department of Geosciences and Natural Resource Management, University of Copenhagen, Denmark \\ f GEOMAR Helmholtz Centre for Ocean Research Kiel, Germany
}

The recent marine carbonate world comprises two major compartments: (1) the surface domain of the photozoan carbonates, confined in space by water depth and by the penetration of light, and (2) a deep domain, where heterozoan mound-builder guilds directly forage on fluxes of nutrients, which primarily percolate from the photic zone and/or are generated by in situ benthic processes. Locally, giant cold-water coral mounds tower up to heights of 150 to $250 \mathrm{~m}$ above the sea floor, in general between 500 and $1300 \mathrm{~m}$ water depth and within sharply delineated provinces. Some 15 years of research on these giant mound provinces conveys a picture of their distribution in space and possibly sheds light on controls, acting in concert. Globally, there is no counterpart for the prolific North Atlantic Mound Basin (NAMB). A chemical control is seen by an overlay of the mound provinces on a map of the aragonite saturation horizon (ASH). An external physical control is inferred from the position of the mound provinces, girdling a vigorous North Atlantic subtropical gyre system and clustering close to the roof of the intermediate to deep water masses of a dynamically stratified ocean. On the eastern boundary of the NAMB, nutrient fluxes are enhanced by mixing processes, driven either by internal waves between Galicia and the Shetlands, or by the vast and heterogeneous Eastern Boundary Upwelling System along the Iberian/African margins down to $10^{\circ} \mathrm{N}$. Early diagenesis by carbonate dissolution and re-precipitation driven by convecting or advecting internal fluids can contribute to stabilize such constructions, facilitating an exuberant vertical accretion. It is speculated that in the North Atlantic Ocean, the deep-water carbonate factory outclasses in size the shallow water coral reefs.

Giant mound formation is a recurrent play of Life since the dawn of the metazoans (Nama Group, Upper Neoproterozoic), however with actors and plots, varying from act to act. Remarkably, literature reports only three occurrences of deep-water mounds in the Phanerozoic: the modern ocean, possibly the Danian, and the Carboniferous. Some striking parallelisms in the development of the Atlantic and the Paleo-Tethys oceans, combined with the developing insights in the controls on deep-water mounds in the present ocean, invite for a comparative study. This has the potential to eventually shed light on the full circulation pattern of the Paleo-Tethys Ocean, surface and deep. Comparative studies will build upon (1) modeling of ocean circulation constrained by the record of deep-water carbonate systems and supported by advances in tracer and proxy tools, and (2) field studies on representative and accessible continental locations. The mound route that develops in Morocco under the auspices of IOC-UNESCO will provide to multi-disciplinary teams with marine and continental experience opportunities for confronting observations from the modern ocean and on key records of past oceanic basins. It has the potential to eventually qualify for a UNESCO recognition as World Heritage.

\section{Introduction}

In his foreword of the comprehensive source book "The History and Sedimentology of Ancient Reef Systems" edited by George D. Stanley in 2001, Noel P. James states that ever since Darwin reported on his investigations of far-flung reefs, these structures have held an unending

\footnotetext{
* Corresponding author.

E-mail address: jeanpierre.henriet@ugent.be (J.P. Henriet).
}

fascination for Earth scientists. For James, the very word "reef" conjures up restful, tropical images wrapped in warmth and displayed in shimmering colors. A particular phrase from Stanley's volume however stuck in James's mind: "reefs are a plethora of paradoxes".

What James might have overlooked is that over half a century before Charles Darwin published "The structure and distribution of coral reefs" (1842), his grandfather Erasmus Darwin (1731-1802) had already commented on the hazardous "calcareous earth" in the additional notes to his opus "The botanic garden" (1791, Note XVI, p. 32): “... marine animals named coralloids raised walls and even mountains by the 
congeries of their calcareous habitations, these perpendicular coralline rocks make some parts of the Southern Ocean highly dangerous, as appears in the journals of Capt. Cook". The fascination of Earth scientists for tropical images in shimmering colors had clearly been preceded by concerns of navigators.

As a matter of fact, Stanley (2001) refers to two possible origins of the word reef, both related to navigation hazards: either an old German or Norse term ("rif") for a ridge of rock that lay as an obstruction near the surface of the water, or "Er Rif", an Arabic term given to "hills" found by traders in shallow waters between Tangier and Melilla. He furthermore endorses the requirement of warm, well-lighted, shallow marine conditions: "reefs are restricted to tropical and subtropical settings, primarily on western parts of oceans, ranging today between $20^{\circ}$ and $30^{\circ}$ north and south of the equator" (Stanley, 2001, p. 1-2). Understandably, when Hovland et al. (1994) reported carbonate build-ups in the cold and dark waters of Porcupine Seabight west of Ireland, about $52^{\circ}$ north in the eastern North Atlantic, in depths ranging between 750 and $900 \mathrm{~m}$, labeling them as "reefs" was not straightforward. Hovland et al. (1994) referred to "seabed mounds (carbonate knolls?)".

In the wake of the publication of Hovland et al. (1994), a vast momentum of European projects set off in 1997 to unveil thousands of giant deep-water carbonate mounds on the northwest European continental margin, buried or surfacing. They range in general between 30 and $250 \mathrm{~m}$ in height and sometimes coalesce to complex ridges (Henriet et al., 1998; De Mol et al., 2002; Huvenne et al., 2003; Wheeler et al., 2007). The surface mounds are commonly covered by thriving cold-water coral ecosystems rivaling in color and luxuriance anything tropical reefs can offer. That very same year, the seminal SEPM Special Publication No. 56 on cool-water carbonates was introduced with the statement "Cool-water carbonates have always been part of sedimentary geology, but never at the forefront" (James, 1997, p. 1). On the European margins, deprived of warm-water reefs, the vast provinces of cold-water coral ecosystems would soon move to the forefront, to get high visibility in particular at the 2nd International Symposium on Deep-Sea Corals held in Erlangen, September 2003 (Freiwald and Roberts, 2005). While the name cold-water coral "reefs" was still opportunistically used by scientists towards European policy to spur - not without success - the protection of those deep-water ecosystems in Irish waters which by miracle had escaped deep-water trawls, the term "cold-water coral mounds" soon gained widespread acceptance in scientific literature.

Biogenic deep-water mounds have also been reported on the western margin of the North Atlantic, from water depths of 1000-1300 m (Paull et al., 2000). "Modern deep-water coral mounds north of Little Bahama Bank: criteria for recognition of deep-water coral bioherms in the rock record" (Mullins et al., 1981) possibly set the stage for confronting the emerging insights in the world of deep carbonate mounds of the modern ocean with the vast fossil record of carbonate build-ups. This exercise is presently continued and amplified by the international network COCARDE ("Cold-water Carbonate Reservoir Systems in Deep Environments", Henriet et al., 2011) which, for the analysis of the fossil record, in particular draws from the vast Paleoreef data base developed in the comprehensive SEPM Special Publication No. 72 - "Phanerozoic Reef Patterns" (Kiessling et al., 2002).

In the introduction of that volume, reefs are defined as "laterally confined biogenic structures, developed by the growth or activity of sessile benthic organisms and exhibiting topographic relief and (inferred) rigidity" (Flügel and Kiessling, 2002, p. 3). This definition is quite close to that of Wood (1999, p. 5): "a reef is a discrete carbonate structure formed by in-situ or bound organic components that develop topographic relief upon the sea floor". Such broad and simple definitions allowed both Wood (1999) and Flügel and Kiessling (2002) to trace the evolution of reefs through Earth history, highlighting the ways in which reef communities can differ, and illuminating processes common to the formation of all reefs. Flügel and Kiessling (2002) acknowledge that some authors might use terms such as bioconstructions, buildups or bioherms, and consider these as synonymous with their reef definition. In the present review paper, mounds may be regarded as a subset of reefs sensu Flügel and Kiessling (2002), further individualized by a distinct context and significance.

The question of reefs and mounds indeed transcends semantics. The historical context of "reefs" as shallow water hazard, the longstanding fascination for the images of tropical reefs, and even a tenacious industrial bias for shallow water processes in the development of geomodels, reservoir models and porosity distribution in reef carbonates have long cast a shadow on the nature and significance of carbonate constructions in deeper water. Yet, ocean drilling on the Irish margin soon revealed the extraordinary significance of cold-water coral mounds, for instance as high-resolution environmental archive (IODP Exp. 307, Ferdelman et al., 2006; Foubert and Henriet, 2009; Thierens et al., 2010). As developed later, they may hold - far more than the shallow-water carbonate factory - a key to the dynamics of deep and intermediate water circulation, heartbeat of the Earth's climate machine. Furthermore, on a background of new discoveries of giant hydrocarbon accumulations in ancient mounds, the confrontation with the modern world of carbonate mound systems - in particular revealed by ocean drilling - becomes an eye opener and spurs new exploration insights and strategies (Philippe Lapointe, Total E\&P, COCARDE Oviedo workshop 2009, in Henriet et al., 2011).

Such confrontation of ideas between the academic and industrial world in carbonate research, and between researchers of the modern systems and those of the fossil record calls for a forum, a broadband field laboratory which can be turned into a meeting place and a reference site. This paper narrates how a unique reference route is being developed for such purposes in Morocco, with the potential to qualify as a UNESCO World Heritage Route. In parallel, it invites for a ramble through some processes and possible controls on mound nature and origin, without any pretension to comprehensiveness, but with an avowed zest for the deeper realm of the carbonate world, in particular the Atlantic one. As regards the Mediterranean, the present paper will only evoke the cold-water coral mounds in the gateway region between the Atlantic and the Mediterranean, in relation to the proposed Moroccan mound Heritage Route. The specific nature of the Mediterranean as a confined basin justifies a stand-alone review of its deep carbonate world.

\section{Cold-water coral reefs in canyons and on glacial margins}

The world of cold-water coral habitats comprises build-ups which qualify for a definition of reefs, yet that we shall not discuss here. These are on one side the vast cold-water coral fields thriving in interglacial times on former glaciated shelves, such as the Norwegian Sula, Rost, Traena, Fugloy, Iver and Stjernsund reefs (Freiwald et al., 2004; Fosså et al., 2005; Rüggeberg et al., 2011), or the small and patchy reefs on rocky spurs off Scotland (Mingulay reef, Roberts et al., 2009). Though some of them feature an internal facies, comparable to that of deep-water coral mounds, the position of these shelf reefs within the reach of waxing ice sheets does not allow them to develop to the exceptional dimensions in space and time, such as observed in the mound provinces on the deeper slopes of northeastern Atlantic margins.

The other habitats not discussed in this paper are the deep coldwater coral colonies in canyons (De Mol et al., 2011; Huvenne et al., 2011, 2012). Perched under overhanging cliffs or high on rocky spurs in highly stressed environments, they form significant refuges, but again they are in general not in a position to develop to the giant build-ups further considered here. The development of a canyon head with its associated zones of sediment instability may however impact on mound provinces. On the western flank of Porcupine Bank, for instance, mounds are concentrated along the edges of a canyon head or are associated with a complex fault system, traced around the canyon head (Mazzini et al., 2011). 


\section{Small mounds and giant mounds in the recent ocean}

The remarkable resolution achieved in seismic imaging, multibeam bathymetry and habitat mapping in Porcupine Seabight, in the Bay of Biscay and on the Moroccan North-Atlantic margin in water depths ranging between 300 and $1300 \mathrm{~m}$ has shed light on vast fields of small cold-water coral capped hummocks, barely a few meters in amplitude (Masson et al., 2003; Wheeler et al., 2008; Huvenne et al., 2009; De Mol et al., 2011; Foubert et al., 2011; Wheeler et al., 2011), or coralcapped giant ripples, up to 10 to $20 \mathrm{~m}$ in amplitude (Mienis, 2007; Correa et al., 2012). In the early days of modern mound exploration on the Irish margin, the frequent spatial association of such fields of coral-capped hummocks and giant cold-water coral mounds fuelled the hypothesis that those small mounded features possibly could represent the embryonic stage of giant mounds, and still recently, contrasting views persist on this matter (Wilson et al., 2007; Foubert et al., 2011; Wheeler et al., 2011). In a depression between outcropping giant carbonate mounds in the Belgica Mound province in Porcupine Seabight, small mounded features abound on sediment waves and small ridges and furrows: the Moira Mounds (Fig. 1) (Wheeler et al., 2008, 2011). Foubert et al. (2011) argue that they can be explained by the interaction of cold-water coral growth and sediment baffling, in response to strong bottom currents and high sediment fluxes. The targeted coring of minimounds on Odet Spur, south of the Guilvinec Canyon in the Bay of Biscay (De Mol et al., 2011) furthermore revealed that the debris of skeletal benthos, in general cold-water corals, formed no more than a centimeter- to decimeter-thick veneer at the surface of those small topographic elevations, which apparently had been shaped in a clayey substratum by strong bottom currents. Likewise, Masson et al. (2003) had demonstrated that corals, though prominent at the surface, are not a major contributor to the building of the small Darwin Mounds in Rockall Basin.

In a way, one might argue that such hummocky or wave-shaped fields of small mounded features or ridges form a biologically stabilized, and possibly even the biologically enhanced expression of a boundary layer, a shear zone, where strong oceanic bottom currents have draped the seabed with large sediment waves. It should be noted that such fields of sediment waves topped with corals can also climb the flanks of larger mound structure (e.g. Thérèse Mound, Belgica Mound province, Foubert et al., 2011). The patchy settlement of opportunistic cold-water corals on the highs and the concurrent sediment baffling could actually mold small hummocks on these wave fields, and stabilize them. Differential erosion can contribute to the further shaping and enhancement of individualized hummocks. Current velocities decrease by

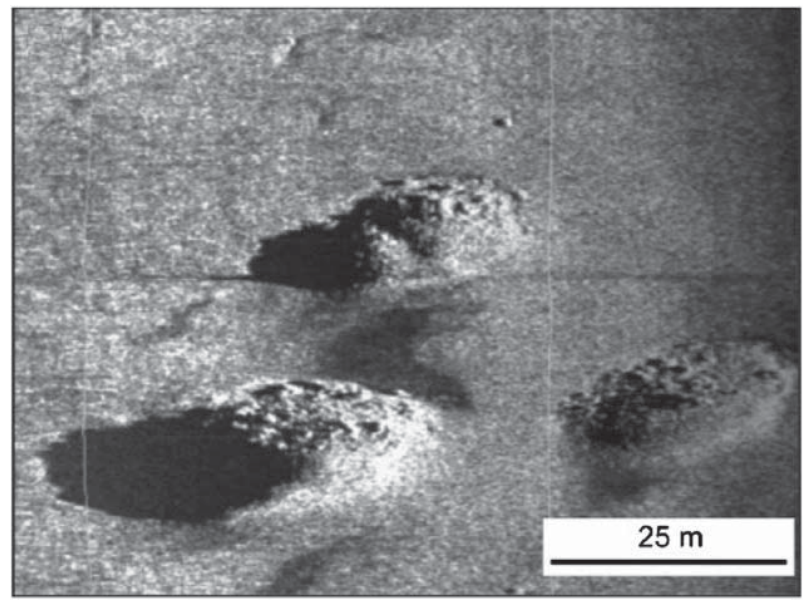

Fig. 1. The Moira Mounds in Porcupine Seabight (Foubert et al., 2011; Wheeler et al., 2011) were, jointly with the Darwin mounds in Rockall Basin (Masson et al., 2003), among the earliest described "small mounds" on the North-West European continental margin. They are coral-capped, circular in shape with a cross section up to $30-50 \mathrm{~m}$, and a few meters high.

Sidescan sonar image is from Wheeler et al. (2011). drag over the coral-capped highs and concurrently increase in the gullies separating the small mounds (Bernoulli effect), as argued by the coarse-grained lag deposits (Odet Spur, De Mol et al., 2011).

The extensive multibeam coverage already available on European and North African margins corroborates that within such hummocky ridge fields, none of the small mounds appears to compete in height with adjacent ones. The most likely limiting factor in the baffling process is the maximal height of saltation of the sediment grains within the bedload transport layer. As Foubert et al. (2011) already had concluded for the Moira Mounds, such small buildups should be regarded as simple responses to stressed conditions in strong bottom currents and high sediment fluxes, rather than as an initial phase of extensive mound growth. The giant mounds, which started to grow some 2.5 Ma (Exp. 307, Kano et al., 2007), are also often molded by moderate to strong currents (Magellan mounds, Huvenne et al., 2007) and draped by contourite drifts (Van Rooij et al., 2003) (Fig. 2). A long-term, persistent or recurrent high-energy environment may consequently have been the possible common control for the spatial co-occurrence in Porcupine Seabight of both giant mounds and large-scale sediment wave fields and/or erosional furrows on the present sea floor, on which small mounded features abound.

\section{From stromatolites to giant mounds: a prelude of $\mathbf{1 . 5}$ to 2 billion years}

It is commonly accepted that the stromatolites of the late Precambrian provide the earliest record of carbonate build-up processes.

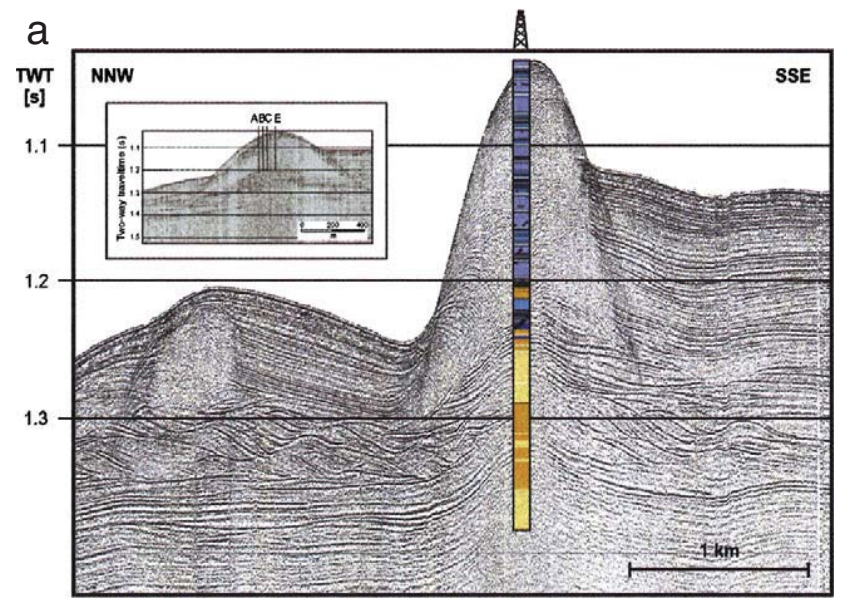

b

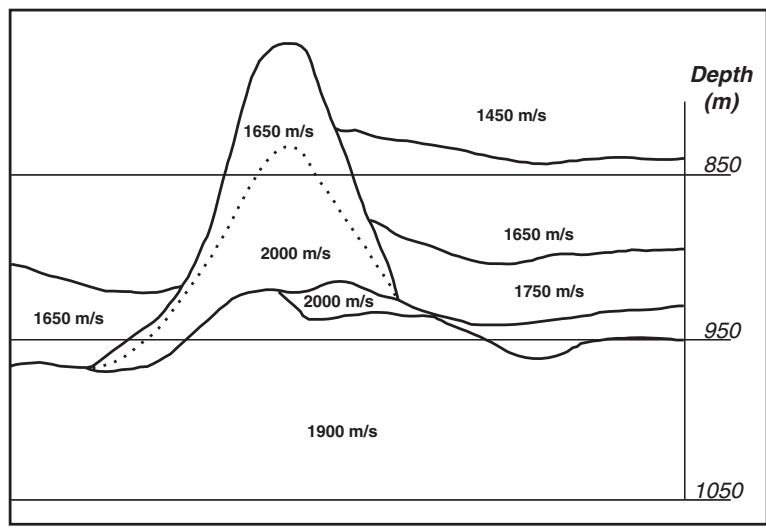

Fig. 2. High-resolution seismic section through Challenger Mound, Belgica Mound province (top), Porcupine Seabight (Foubert and Henriet, 2009). This mound, draped by contourites and drilled by IODP Exp. 307, has a total height of $155 \mathrm{~m}$ and exemplifies a medium-sized "giant mound". The depth model (bottom) illustrates how the mound roots on the crest of an erosional escarpment, some $30 \mathrm{~m}$ high (Henriet et al., 2002). 
Stromatolites were first defined by Kalkowsky (1908) in the German Buntsandstein and are widely regarded as layered, early lithified, authigenic microbial structures, commonly domical or columnar in form, that develop at the sediment-water interface in freshwater, marine and evaporitic environments (Riding, 2011). Stromatolites are spotted in up to 3.5 Ga old strata, but many Precambrian examples, especially those older than about $1 \mathrm{Ga}$, appear to contain, and in some case may entirely consist of, precipitated abiogenic crust (Riding, 2011). In a way, the early marine stromatolite record can be read as long-term change from less to more biogenic. The players in the biogenic deposits remained unchanged for at least 2.5 billion years. The first identifiable cyanobacteria - the Earth's oldest "living fossils" (Schopf, 1999) - are recognized in about 2.5 Ga old strata, at the dawn of the Proterozoic Eon, when stromatolites became abundant and diverse (Wood, 1999), and they are still alive today.

Recent domical to columnar forms are indeed well documented along the shoreline of the seasonally hypersaline Shark Bay in Western Australia. Externally, these recent columnar microbial carbonates can closely resemble very ancient examples, however internally they are less well layered and coarser grained. The decimetric to metric domes in the fossil record are in general more distinctly laminated than the Shark Bay example. Described by Aitken (1967, p. 1171) as "thrombolitic stromatolites", the Shark Bay stromatolites are largely composed of fine sand (Logan et al., 1974). The high accretion rates which shaped these domes are likely due to the combined presence of thick soft microbial mats that contain abundant extracellular polymeric substance (EPS) (Decho et al., 2005), and rapid sediment grain supply. The early lithification necessary to support such large columns mainly occurs in, or below, the lower part of the mat. Thus, grainy current-swept conditions, thick soft surface mats, and early subsurface lithification help the decimetric, and locally metric, columns to develop (Riding, 2011).

The availability of both modern and fossil examples allowed unraveling the fine mechanism of growth of stromatolites, and shed light on a fundamental driver. Cyanobacteria, acclaimed by Andrew Knoll (2003) as Life's microbial heroes, took advantage over primitive anoxygenic photosynthesizers by an aggressive technological innovation, using chlorophyll to capture light energy and giving off oxygen by oxygenic photosynthesis. While in the primitive process, the hydrogen needed to combine with carbon dioxide to build glucose was extracted in an economic way from hydrogen sulfide, in the advanced photosynthesis the much more available water molecules are split, however, at a much higher energy cost. In modern stromatolites, oxygenic cyanobacteria and anoxygenic photosynthetic bacteria live apparently harmoniously in layered communities, further able to coexist because they have different light-capturing pigments. Though much of the sunlight is soaked up by cyanobacterial chlorophyll, this does not snuff out the underlying bacterial photosynthesizers because their bacteriochlorophyll is sensitive to wavelengths of light that seep through to where they live (Schopf, 1999). The cyanobacterial sheaths further trap sediment by the slimelike extracellular polymeric substance. But when surface is flooded with mud, the filamentous cyanobacteria respond by sloughing off their mucilage investments and swiftly gliding upward to the sunny surface. Since the photosynthetic bacteria in the undermat need to harvest light too, if the cyanobacteria move upward the undermat microbes follow suit. This in turn frees space soon occupied by anaerobes that move up from below to feed on whatever organic matter was left behind.

While being constrained to a boundary layer, stromatolites were able to reasonably catch up with a rising sea level, which could lead to the build-up of impressive thicknesses of hundreds of meters in transgressive system tracts. Thick carbonate platforms with most of the essential features of those found during the Phanerozoic Eon were already well developed by $2.6-2.3 \mathrm{Ga}$, at the onset of the Proterozoic Eon (Grotzinger, 1989). Knoll's (2003) preferred example of the "Great Wall" in the Bil'yakh Group along the Kotuikan River in northern Siberia is a breathtakingly well exposed, two-dimensional stratified stack, a slender mesa of carbonate beds of approximately constant thickness, as flat today as when formed nearly 1.5 billion years ago.

\section{Neoproterozoic mounds: heralding the social conquest of the Earth}

The cliffs of the Namibian Skeleton Coast offer one of the best showcases of a great Neoproterozoic ice age: a warm-water cap carbonate sequence, blanketing glacial deposits of the first major ice advance of the middle of the Neoproterozoic. The cap carbonates would become a cornerstone for the Snowball Earth hypothesis, a name coined by Joseph Kirschvink (Caltech) in the early 1990's (Harland and Rudwick, 1964; Hoffman et al., 1998; Hoffman and Schrag, 2000; Lenton and Watson, 2011). This Sturtian glaciation, which ended about $700 \mathrm{Ma}$, would be followed by two more glacial episodes, the Marinoan (also called Varangar) glaciation, ending $635 \mathrm{Ma}$, and the less severe and shorter advance, the Gaskiers, which took place about $580 \mathrm{Ma}$ (Halverson et al., 2005).

It has been speculated that the rise of the metazoans and the spectacular radiation of animals following Snowball Earth, the so-called Cambrian explosion which effectively stretched between 575 and $525 \mathrm{Ma}$, was intimately linked to an intrinsic adaptation of Life towards cooperative behavior. This came into being not after, but during the extreme conditions of ice ages (Lenton and Watson, 2011). Extreme glaciations, environments in which many small populations of protoanimals may have been isolated from one another for very long periods of time, would have produced the conditions in which altruistic traits most readily evolved (Boyle et al., 2007). This might exemplify a radical move from Dawkins' (1976) "selfish gene" to Wilson's (2012) "Social Conquest of the Earth". The development of altruistic genes would have been to these animals and their cells' long-term advantage, because it would help the entire community to survive, including themselves. The hypothesis of Boyle et al. (2007) leads to a clear prediction that evidence of the first ancestors of modern animals should appear during or straight after the interval of global glaciations (Lenton and Watson, 2011). This apparently found support when Love et al. (2009) reported the first biomarker evidence of the presence of sponges before the end of the second great glaciation (the Marinoan), about $635 \mathrm{Ma}$.

That very same year however, Neuweiler et al. (2009) pushed back evidence of the earliest animals by some 200 Myr. In the Mackenzie Mountains, north-western Canada, coalescing small microbial reefs of Neoproterozoic age (1100-780 Ma) of the Little Dal Group, each 1-8 $\mathrm{m}$ thick, had built composite, three-dimensional reefs up to $500 \mathrm{~m}$ in height and $3 \mathrm{~km}$ in diameter (Wood, 1999). Neuweiler et al. (2009) found that the reefs of the Little Dal Group contain a carbonate rock texture, already familiar from sponge-rich Phanerozoic carbonate mud mounds. It is characterized by authigenic calcium carbonate and irregular, secondary voids containing internal sediment with a so-called polymud fabric. This observation suggests that metazoans were already present in reefs before Snowball Earth, or at least matched the earliest excursion towards icehouse conditions, a cooling spike at about $810 \mathrm{Ma}$ (Halverson et al., 2005), and they persisted through the Late Proterozoic glaciations.

A second clue to the presence of metazoans in large Neoproterozoic reefs is found in Namibia, where spectacular pinnacle reefs occur in the Nama Group in South and West Namibia (Fig. 3). They reach up to 100 $\mathrm{m}$ in height and $3 \mathrm{~km}$ in width (Wood, 1999) and range in age from approximately 550 to $543 \mathrm{Ma}$ (Grotzinger et al., 2000), just antedating the Cambrian. Their spatial pattern has been interestingly surveyed and modeled in 3D (Adams et al., 2005). Skeletal grainstones may have provided firm sites for initial mound nucleation (Schröder et al., 2001). The basic facies is still dominantly microbial, comprising stromatolites and thrombolites. However, skilled niche-players, maybe carefully avoiding to cast shadow on the photosynthetic surfaces, apparently started to grow in sheltered depressions between thrombolite heads of the Huns Member pinnacle reefs (middle Nama Group) (Wood, 1999). An alternative, more trivial scenario is that these calcified organisms were 


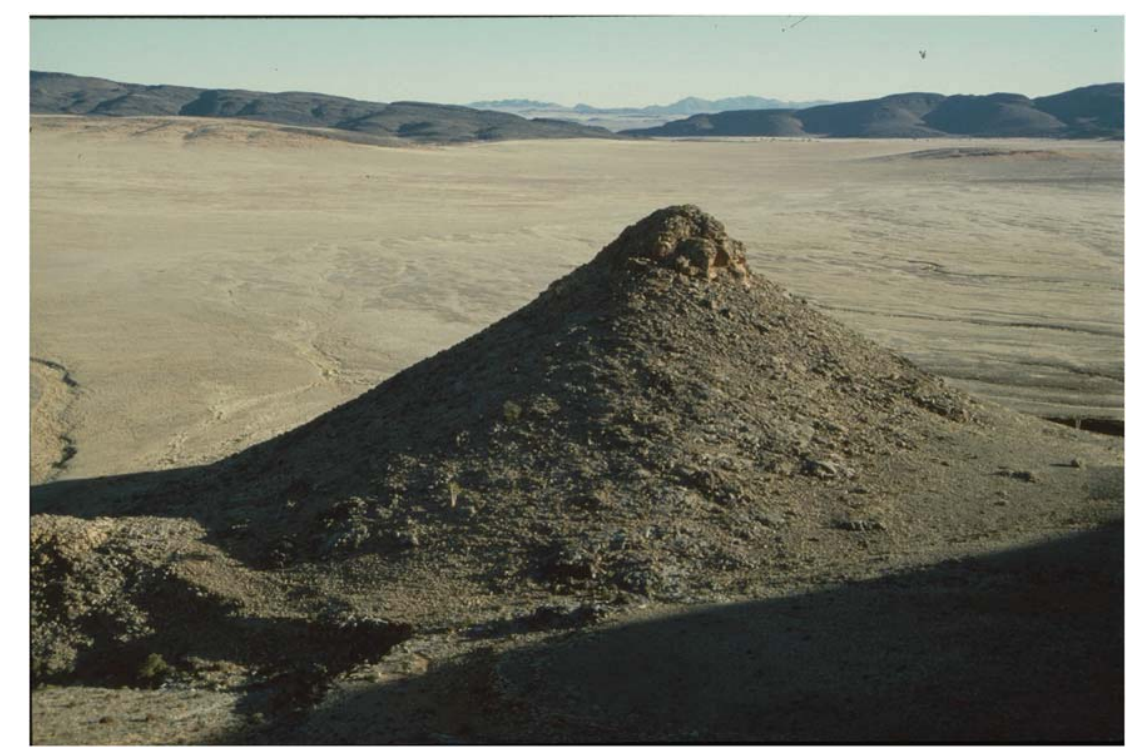

Fig. 3. The pinnacle-shaped Late Neoproterozoic Nama Group mounds, Namibia, are considered as the oldest giant mounds in the geological record, providing direct evidence of microbial build-up and metazoan presence. They reach up to $100 \mathrm{~m}$ high and $3 \mathrm{~km}$ wide.

(Picture: S. Schröder, University of Manchester).

attached as epibionts to algae and upon death or dislocation of the algal components; they were simply swept as detrital particles into the depressions between thrombolites (Grotzinger et al., 2005). These organisms featured goblet-shaped forms of unknown affinity, but possibly poriferan. They are preserved as molds and were either non-skeletal or only weakly mineralized. In the Omkyk Member mounds (basal Nama Group), thickets of Cloudina, weakly skeletonized, sponge-like suspension-feeders of global distribution, became abundant especially in the upper parts of the reefs (Wood, 1999). Remarkably, many Cloudina specimens reported in Neoproterozoic seas show holes that have been bored trough their shells by predators (Bengtson and Zhao, 1992). A popular view is that the shells evolved as an innovative means of defense, which the predators then evolved a way to drill through. The co-evolutionary arms race had begun (Lenton and Watson, 2011). Bio-erosion of cold-water corals by predators is still a prominent process in modern cold-water coral mounds (Beuck and Freiwald, 2005; Beuck et al., 2007; Wisshak and Tapanila, 2008).

Most researchers so far have identified the onset of metazoan reefs near the start of the Cambrian (Copper, 2001; Stanley, 2001), concurrent with the rise of the archaeocyathid sponges. The Little Dal and Nama Groups bring evidence of early courting of microbes and metazoans, yet with little evidence that metazoans in Neoproterozoic times already contributed in a significant way to reef building, neither as framework builders nor as sediment bafflers (Grotzinger et al., 2005).

\section{The evolution of the Phanerozoic reef ecosystem}

Large mounds of the Phanerozoic apparently built upon a higher complexity, a higher level of diversity, a "social" organization ruled by consortia of microbes and metazoans, functionally organized in "guilds" (Fagerstrom, 1991) as constructors, bafflers and binders. To these builders, one should add the destroyers and dwellers. Through mechanisms yet to elucidate, this more complex organization seems to have conferred to mounds the power to transgress the confinement of any boundary layer. There is little doubt that the vibrant ecosystem studies that presently develop on recent cold-water coral mounds, adding to the vast studies on warm-water reef ecosystems and completed with ex-situ experimentation in continuous high-pressure bioreactors
(Zhang et al., 2010), will in some future shed more light on the intricate interactions and exchanges of services within such a complex ecosystem, which control the initiation, growth and demise of giant carbonate mounds.

A genetic model for metazoan-ruled mounds, displaying the elegance of the growth model outlined by Schopf (1999) for stromatolites, is still remote. Somewhere in the "Cradle of Life", Schopf (1999) pondered if stromatolites argue for a "Volkswagen Syndrome" - a lack of change of external form that masks internal evolution of the working parts. The constancy of actor and plot in the cyanobacterial ecosystem (Schopf's "status quo evolution") however argues for very little internal evolution over 2.5 billion years. This simplifies the analysis of the functioning of the working parts. In contrast, Phanerozoic mounds might possibly over-qualify for the cited syndrome. Since the terminal Proterozoic, the external shape of giant mounds does prove remarkably simple and constant, while the working parts show an evolution, with a sense of turbulence that might defy the most elementary common sense in car engineering. The evolution of working parts considered here implies in particular an evolution of ecosystems and their internal functional exchange processes, rather than an evolution of species. The challenge is to identify the red thread, the Grand Engineering Scheme in these consecutive experiments of Nature, which secured the longevity of the giant mound building phenomenon.

Some innovative strategies of collaboration/competition of species did prove highly productive, leading to relatively long-lived, stable ecosystems which boosted reef growth. But either through a failure of some internal "working parts", or through foreign invaders or severe environmental changes, the whole reef ecosystem could suddenly collapse. The switch to altruism and inter-dependency in the complexity revolution, which had heralded the Phanerozoic Eon, may also have introduced an intrinsic weakness: cheaters or weak links in the association may fragilize the ecosystem, as suggested by Lenton and Watson (2011). But in parallel, the new complexity added to an incredible resilience. Throughout Phanerozoic times, collapses and eclipses were in general followed by a rebound of ecosystems and strategies, which resulted in resumed reef buildup. Evolutionary innovations can however not be uncoupled from environmental changes: "the evolution of the Phanerozoic reef ecosystem reflects changes triggered by evolutionary innovations and variations in global controls and regional controls at different 
scales" (Flügel and Kiessling, in Kiessling et al., 2002). Incidentally, also in this statement the word "reef" may be readily substituted for "mound".

In the following sections, some key moments in evolutionary innovation in reefs are briefly reviewed, largely following Kiessling's (2001) template and not seeking comprehensiveness, but simply with the aim to draw a relevant evolutionary framework as background for the planned mound World Heritage Route. Next follows a discussion of some insights in regional controls on mound development at different scales, gained in particular through the study of recent carbonate mound provinces.

\section{Evolutionary innovation and global controls: a play in seven acts, with varying actors and guilds}

The evolution of reef ecosystems during the Phanerozoic Eon shows a long-term trend, modulated by harmonics, and punctuated by mass extinctions (Fig. 4). The microbial carbonate world, which had steadily waxed towards Proterozoic times, when the reign of the cyanobacteria came to an apogee, seems to irreversibly wane during the Phanerozoic Eon. This trend is illustrated on Fig. 4. The width of the dark gray spindle is a measure of microbial carbonate abundance, after Riding (2005). In parallel, metazoan diversity would in general steadily amplify, as shown by the width of the light-gray spindle. These long-term trends are punctuated by repeated episodes of ecosystem collapse and recovery. It has been suggested that the collapse of metazoan ecosystems set the clock back to bacterial carbonates, as disaster forms (Schubert and Bottjer, 1992), as a default option sometimes lasting for several millions of years, but this is questioned by Riding (2005). The notch in the composite spindle diagram on Fig. 4, midway the Phanerozoic, highlights the Early (and/or Late - depending on authors) Permian-Triassic Reef Eclipse, that splits the record of Phanerozoic reef ecologies in two sets of three to four acts each (Wood, 1999; Kiessling, 2001; Stanley, 2001; Kiessling et al., 2002; Kiessling, 2009).

Act 1. While stromatolites first declined, complex reef communities evolved in the Early Cambrian with the rise of the archaeocyathid sponges. With the near extinction of the latter at the end of the Early Cambrian, stromatolites and calcimicrobes would nearly be the only reef builders, until the Early Ordovician (Tremadocian).

Act 2. In the Middle to Late Ordovician, tabulate and rugose corals as well as stromatoporoids diversified and dominated many reef structures. Silurian and Devonian reefs exhibit a high degree of similarity. Shallow water reefs were dominated by tabulate-rugose corals, stromatoporoids, calcimicrobes, bryozoans and calcareous algae. The mass extinction terminating the Middle Ordovician to Late Devonian reef interval, the Frasnian-Famennian or Kellwasser event (Mc Ghee et al., 1986), can be seen as the Phanerozoic biotic event with the greatest impact on reef ecosystems. The majority of Famennian reefs were dominated by calcimicrobes and stromatolites.

Act 3. Reefs which formed subsequent to this event were completely different in biotic composition and constructional reef type. Starting in the Famennian and proliferating in the Tournaisian to Early Visean, a distinct type of reef structure developed, the so-called Waulsortian bank (de Dorlodot, 1909). It dominated in deep-water ramp settings and is characterized by abundant micrite and marine cement, and few traces of macroscopic skeletal organisms. The Pennsylvanian started with a major decline in global reef abundance and a subsequent takeover of various calcareous algae as main reef builders. During the Permian, sponges gradually became more important reef builders.

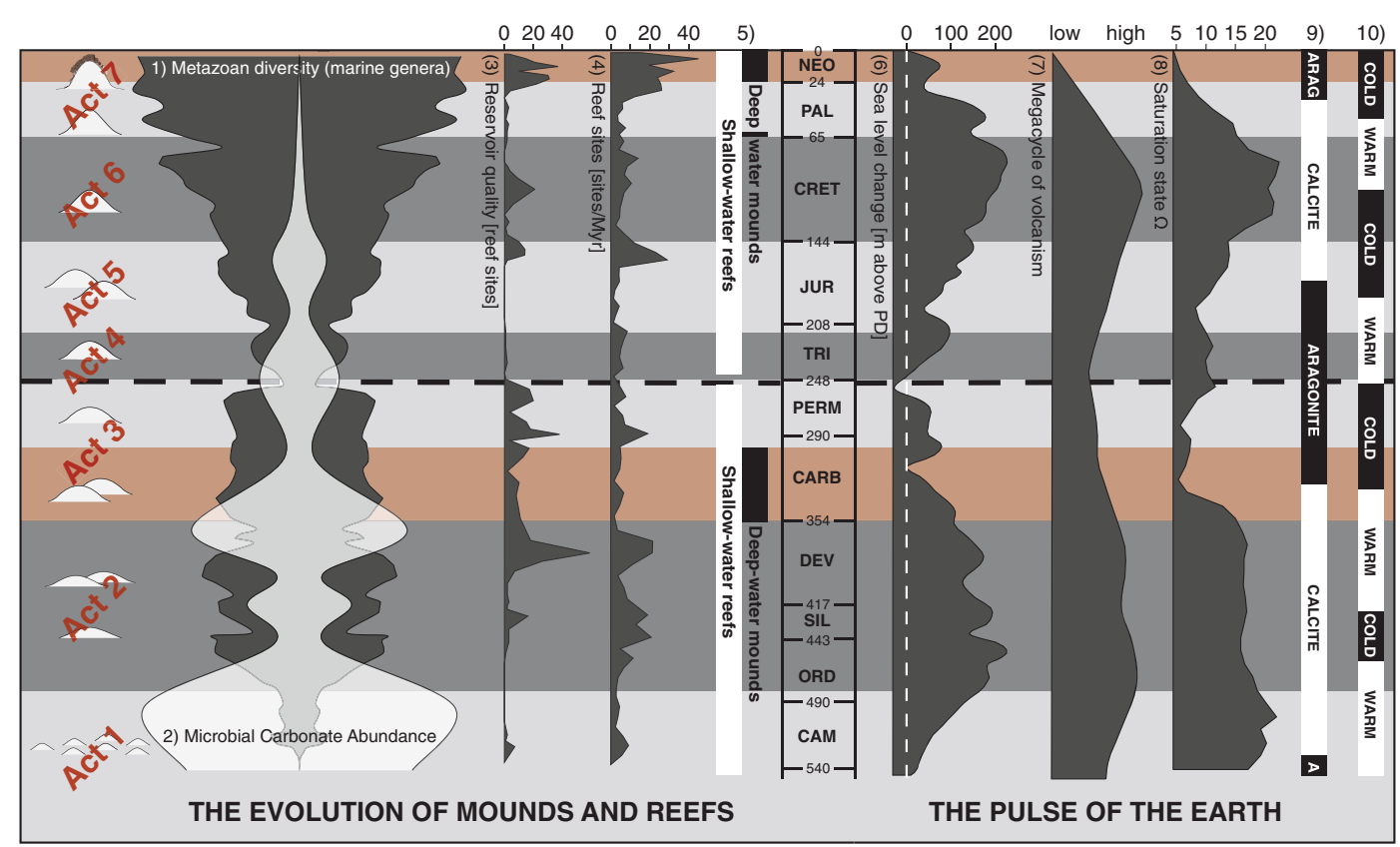

Fig. 4. The evolution of Phanerozoic mound and reef ecosystems can be described in $3+4$ acts, separated by the Permian-Triassic Reef Eclipse. The steady evolution from microbial dominance to metazoan prominence in mounds and reefs is evoked through superposition of (1) metazoan diversity (dark gray spindle) and (2) microbial carbonate abundance (light gray spindle) (modified after Riding and Liang, 2005a,b). (3) Numbers of reef sites of reservoir quality and (4) the frequency of reef occurrence (sites per Myr) are derived from Kiessling et a . (2002). The red ribbons flag the two intervals of documented deep-water mounds (5). The Pulse of the Earth: environmental conditions are illustrated by (6) mean sea level relative to present day (Haq et al., 1987; Hardenbol et al., 1998; Haq and Shutter, 2008; compiled by Snedden and Liu, 2010), (7) the volcanism megacycles after Alfred Fisher (in Van Andel, 1985), (8) seawater saturation state of calcite (Riding and Liang, 2005a), (9) secular variations in the mineralogy of non-skeletal marine carbonates (Stanley and Hardie, 1998) and (10) periods of cold climate (dark gray) and warm climate (light gray) (Frakes et al., 1992). 
The Permian-Triassic mass extinction set the clock back to microbial, mostly stromatolitic reefs, for some $10 \mathrm{Myr}$, followed by a period of metazoan diversification.

Act 4. Recovery of the reef ecosystem was surprisingly rapid in the Triassic. Middle Triassic microbe-sponge to Late Triassic spongecoral reefs feature many aspects in common with Middle and Late Permian reefs. Some authors wonder to what extent Permian organisms survived in small and isolated refuges (Stanley, 2001).

Act 5. Late Triassic reefs experienced a major innovation with the rise of the scleractinians, in particular zooxanthellate corals. This enhanced the growth potential of reefs in the photic zone and allowed them to thrive in nutrient-limited environments. Corals became increasingly dominant in Late Triassic reefs. This trend continued in the Jurassic, assisted by widespread bivalve mounds in the Early Jurassic and siliceous sponge-microbe reefs during the entire Jurassic. Late Jurassic shallow-water reefs are abundant and mostly dominated by scleractinian corals. Schmid et al. (2001) saw remarkable parallels in growth dynamics between Late Jurassic mounds and Mid-Paleozoic mounds.

Act 6. A poorly understood and sudden reef decline occurred in the earliest Cretaceous, accompanied neither by a mass extinction, nor by any major change in ecosystem structure. These times do, however, concur with the onset of repeated periods of the so-called Oceanic Anoxic Events (OAEs, Schlanger and Jenkyns, 1976), when black shales accumulated in the deep ocean. During the Cretaceous, a gradual shift occurred from coral-dominated to rudist-dominated reefs. Corals would, however, survive the ill-fated rudist experiment, and continue to thrive. The shift towards a predominance of the skeletal factory, paralleled by a strong diversification of planktonic foraminifers, led to a fundamental change from predominantly biologically-induced calcification (predominantly microbial organomineralization s.l., Dupraz et al., 2009) to biologically controlled calcification (bio-mineralization) (Pomar and Hallock, 2008). The total extinction of rudistid bivalves preceded the K/Pg extinction by 1.5 to $3 \mathrm{Ma}$ (Wood, 1999; Stanley, 2001).

Act 7. Just after the K/Pg boundary carbonate platform sediments and small bryozoan mounds of Danian age are exposed in the Danish Basin at Stevns Klint (Surlyk, 1997; Bjerager and Surlyk, 2007). From mid-Danian non-symbiotic scleractinian coral mounds interbedded with low-diversity bryozoans mounds are exposed primarily in Faxe Quarry (Lauridsen et al., 2012; Lauridsen and Bjerager, 2014). The rise of modern-type coral-algal reefs was further underway in the Paleocene. At the Paleocene-Eocene Thermal Maximum (PETM) short-term warming may have led to eutrophic conditions on the shelves and acidification of the oceans, hampering the growth of aragonitic corals, while calcitic larger foraminifera flourished. In the absence of other successful carbonate-producing organisms, larger foraminifera were able to take over the role as the dominant carbonate platform inhabitant (Scheibner and Speijer, 2008). Most of the reef-building coral genera are present by the end Eocene, but reefs are rare until the Oligocene. Reef abundance increases significantly by the Late Oligocene and especially the early Miocene. During the Neogene, a robust coral-dominated reef ecosystem emerged in most oceans. Emergence of the Isthmus of Panama in Pliocene times subdivided a previously broad ocean into today's Pacific and Atlantic Oceans and caused extinctions through changes in nutrients and ocean circulation patterns (Stanley, 2001). Exactly after the closure of the Panama seaway, cold-water coral mounds, built by azooxanthellates, appeared on continental slopes in the North Atlantic, matching the onset of northern hemisphere glaciations at some 2.5 Ma (IODP Exp. 307, Ferdelman et al., 2006).

The development of reef and mound ecosystems through Phanerozoic times can be confronted with global controls (Fig. 4). The two first-order cycles of reef evolution, split by the Early Triassic Reef Eclipse, are mirrored by first-order cycles in sea level (Vail et al., 1977), volcanism and $\mathrm{CO}_{2}$ concentration in the atmosphere (GEOCARB III model, Came et al., 2007), and calcite saturation in the oceans. The latter is a primary control in particular on microbial carbonate accumulation (Riding and Liang, 2005a,b). Higher values of saturation state and carbonate accumulation occur during times of 'calcite seas', and lower values during times of 'aragonite seas', which suggests an integrated pattern of variation in marine $\mathrm{CaCO}_{3}$ precipitation, and consequently in $\mathrm{CO}_{2}$ sequestration, reflecting global geochemical cycles. The differentiation in "calcite" seas and "aragonite seas" is probably linked to secular variations of oceanic $\mathrm{Mg} / \mathrm{Ca}$ ratios (Stanley and Hardie, 1998; Kiessling, 2009). Some caution should, however, be taken when this concept is discussed in the context of carbonate factories in deeper waters, as this classification is primarily based on the mineralogy of inorganic calcium carbonate precipitates, marine ooids and cements collected from carbonate platforms and ramps (Sandberg, 1983). On the diagram of global controls (Fig. 4), attention is drawn to the terminal phase of both first order cycles: the Carboniferous to Permian on one side, and on the other side the trend of lowering sea levels, lowering of the $\mathrm{CO}_{2}$ concentration in the atmosphere and global cooling, which looms large since Cenozoic times.

\section{New views on old mounds}

Remarkably, the literature covering the Phanerozoic record, and by extension the whole story of Life, brings evidence of only three episodes of deep-water mounds - mounds that had not been forced to the deep by platform or ramp subsidence, but could be born in depths beyond $300 \mathrm{~m}$. The first, complex episode is reported in the Carboniferous. Recent data suggest that the Faxe mounds of Danian age might have grown in depths of 200 to $400 \mathrm{~m}$ (Lauridsen and Bjerager, 2014). The third episode started recently, at the onset of Quaternary times. Estimating paleo-water depth from the physical rock record is however a complex issue (Immenhauser, 2009), and it is no surprise that few investigators of the fossil world may ever have envisaged that mounds could nucleate in waters much deeper than the shelf edge or upper slope. As recent ocean studies bring increasing evidence of the wealth of mounds in water depths over 500-600 m, some carbonate scientists might possibly re-visit the record of the past, and consider that also in deep time, the genesis of carbonate build-ups in deeper waters might be more frequent than hitherto presumed. In industrial data sets, seismic dip lines following a carbonate ramp from basin edge down to the occurrence of mounds may provide a fair control on paleowater depth of the mounds.

The Carboniferous episode of deep-water mounds seems to concur with a period of decline of the calcite saturation, when a calcite sea switched to an aragonite sea. The Quaternary episode concurs with a well developed aragonite sea. Considering the occurrence of coldwater corals in Danian mounds (Lauridsen and Bjerager, 2014), the modern aragonite sea might have found its origin at the onset of the Tertiary. In terms of carbonate factory however, there barely could be a stronger contrast than between Carboniferous mounds and Quaternary ones. The Waulsortian mud mounds of Tournaisian to Early Visean times are characterized by a core sediment containing many generations of micrite, micrite-supported cavity systems infilled by marine cements (including stromatactis), and fenestrate bryozoans that are generally considered to lack any skeletal framework (Wood, 1999). Waulsortian mounds formed over a considerable bathymetric range, 
extending from subphotic depths of $300 \mathrm{~m}$ or more to relatively shallow photic conditions in perhaps no more than a few tens of meters of water (Devuyst and Lees, 2001). Schlager (2003) takes the Waulsortian mud mounds as example for the benthic mud-mound factory dominated by biotically induced (mainly microbial) and abiotic precipitates. Lees and Miller (1995) postulate a sequence of polygenic muds or "polymuds": bacterial cells, together with fungal/cyanobacterial filaments and bacterial extracellular polymeric material (BEPM) would produce a mucus-like biofilm which induced precipitation of lime mud at the surface of Waulsortian mounds. It is interesting that already in 1791, Erasmus Darwin had speculated on the role of mucus in carbonate precipitation: "It is probable that animal mucus is a previous process towards the formation of calcareous earth" (Erasmus Darwin, 1791, The botanic garden, Note XVI, p. 32). Devuyst and Lees (2001) found at the base of several buildups in Ireland grumous, clotted and/or peloidal carbonate muds, they consider as a precursor to the formation of Waulsortian polymuds. Neuweiler et al. (1999) concluded that many mud mounds were essentially organomineralic in origin, i.e. formed by mineralization in close association with non-living organic substrates. They further speculated that resulting fabric of polygenetic muds might actually represent ancestral metazoan reef ecosystems, probably sponges. The bryozoans and crinoids present on Waulsortian mounds were probably capable of baffling and trapping locally fine-grained muds, especially from slightly turbid water (Wood, 1999). However, it is difficult to understand how bryozoans baffling alone could create slopes up to $50^{\circ}$ and reefs up to $100 \mathrm{~m}$ high, and Wood (1999, p. 84) suggests that an unrecognized reef framework must have been present.

In the Early Carboniferous, the dominating carbonate platform geometry is a ramp system with deep-water mud mounds that developed after a major transgression (Ahr, 1989). In the Late Carboniferous, the amplitude of high frequency sea-level changes increased significantly up to $100-150 \mathrm{~m}$ (Colpaert, 2007) due to intensified waxing and waning of the continental ice sheets, leading to a wider range of platform geometries, yet ramp systems were still the most abundant. They are identified in the Ural and the Donetz Basin, Northern Europe, North America and the Middle East (Della Porta, 2003).

Mud mounds have been identified not only in Early Carboniferous deeper water successions, but as a most common carbonate factory in a variety of settings and water depths, from the earliest Cambrian to the Late Cretaceous. Global distributions illustrate that mud mounds spanned the planet ranging from tropical to polar circles (Krause et al., 2004). Carbonate mud mounds form the core of the larger, deeperwater Silurian pinnacle reefs of northern Michigan (Sears and Lucia, 1979). Among the many mound occurrences described around the world (Bosence and Bridges, 1995; Monty, 1995; Pratt, 1995), the Frasnian carbonate mounds of Belgium were most likely the first ones to be studied (Dewalque, 1868; synthesis in Boulvain, 2007). The international meeting organized in September 2005 in Paris, on 'Climatic and Evolutionary controls on Paleozoic reefs and bioaccumulations' lead to the publications of two volumes (Álvaro et al., 2007; Vennin et al., 2007). In a theme session "Carbonate mounds: sedimentation, organismal response, and diagenesis" at the 1999 Annual Meeting of the Geological Session of America, Wood (2001) interestingly questioned to what extent reefs and mud mounds are really so different.

The mud mound factory would currently be out of fashion (Schlager, 2003). Mullins et al. (1981), however, suggested that the deep coralcapped mounds in water depths of 1000-1300 m north of Bahama Bank on the Blake Plateau could be regarded as modern equivalents of mud mounds, and when the research on modern carbonate mounds in the deeper realms of Porcupine and Rockall basins took momentum, in the late nineties, it was tempting to speculate that in the core of these coral-capped mounds of the North Atlantic, the microbial world of the mud-mounds might surface again, if only to corroborate an evoked resilience (Henriet et al., 2002). IODP Exp. 307, however, revealed cold-water corals from bottom to top of Challenger Mound, and little solid evidence of microbial control. Ironically, a few months later,
Exp. 310 of IODP drilled the tropical coral reefs in the blue lagoons of Tahiti, providing evidence of up to $30 \%$ of microbialites (Camoin et al., 2012).

IODP Exp. 307 unequivocally settled the nature of the recent coldwater coral carbonate mounds, which clearly contrasts with Carboniferous mound factories. What however got confirmed from drilling Challenger Mound off Ireland and coring Alpha Mound off Morocco was for instance that the aragonite of cold-water coral skeletons indeed can readily be dissolved (Frank et al., 2010), in particular within a sulfate-methane transition zone (Wehrmann et al., 2011). Aragonite either readily vanishes from such 'open' diagenetic systems (Foubert and Henriet, 2009), or it induces re-precipitation within short reach of the dissolution zone. James's rhetoric question "where has all the aragonite gone?" (2005, p. 454), inspired by observations in superficial seabed sediments, might apply to deep-water coral mounds as well. It is tempting to speculate that if in a remote future, one or two hundreds of millions of years from now, petrologists investigate cores from the deeply buried Porcupine mounds, they might echo Wood (1999, p. 84) in speculating that "an unrecognized reef framework must have been present". With all caution to be taken in an actualistic approach, one might consider that the absence of evidence of aragonite framework elements in Paleozoic carbonate systems born in aragonite seas might not necessarily be an evidence of absence (Cherns and Wright, 2000).

\section{Oceanic control on mound provinces: the uniqueness of the North Atlantic Mound Basin (NAMB)}

What recent cold-water coral mounds and Waulsortian mud mounds most likely have in common is an external oceanic control on their setting, which was capable of enhancing the flux of nutrients. In the absence of photosynthesis, substantial fluxes of nutrients are simply crucial for feeding deep-water carbonate factories. Stanton et al. (2000) have convincingly postulated that the Waulsortian mounds of New Mexico are related to the dynamics of internal waves in a stratified ocean, which would have caused mixing of an oxygen minimum zone, rich in organic matter, with better oxygenated waters. The possible control of a stratified ocean on the distribution of deep water carbonate mounds calls for an analysis of mound occurrences in function of the physiography of ocean basins and gateways, in relation to climate drivers and controls, at relevant times in Earth's history to begin with the present.

Whenever the state of knowledge of the distribution of cold-water coral mound provinces in the modern ocean was presented in scientific forums, over the past ten years, the audience was warned that the remarkable concentration of mound provinces in the North Atlantic was an exploration bias, an artifact. Today, it can be considered it is a fact. The intensive charting of continental margins worldwide in particular in the framework of the revision of continental shelf boundaries under the regulation of the United Nations Convention on the Law of the Sea (UNCLOS), and the exploration for mineral and energy resources makes it unlikely that major recent, outcropping cold-water coral mound provinces would have remained unspotted today. This gets confirmed for the North-American west coast (C.K. Paull, pers. comm. 2012).

Any speculation about the privileged occurrence of cold-water coral mounds in the present North Atlantic invites for a reflection on possible causes and controls. What makes the North Atlantic basin unique is a highly dynamic stratified structure. A strong subtropical gyre in the upper water mass, supplied with additional heat from the South Atlantic, produces relatively dense surface water (Fig. 5), which can readily cool in the boreal waters to generate a substantial North Atlantic Deep Water (NADW) that is both cold and relatively saline. This is not the case in the Pacific. Notwithstanding the presence of well-developed subpolar gyral circulation in the North Pacific, surface salinities are significantly lower than in the Atlantic, particularly in the northern part of the basin, and in addition the North Pacific has 


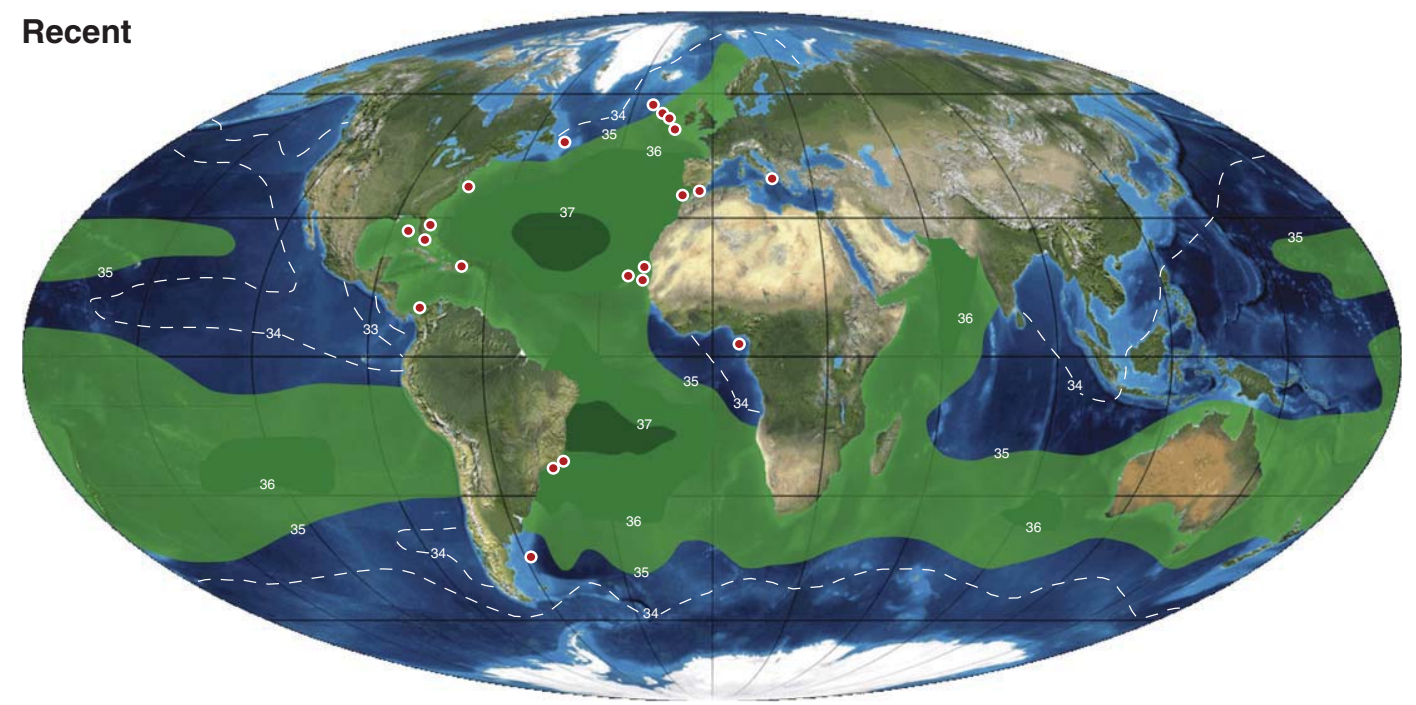

Fig. 5. A strong subtropical gyre in the upper water mass of the North Atlantic, supplied with additional heat from the South Atlantic, produces relatively dense, saline surface water in the North Atlantic, which can readily cool in high latitudes to generate a substantial North Atlantic Deep Water (NADW) that is both cold and relatively saline (Fig. 7). Surface salinities are significantly lower in the North Pacific, which, combined with low sea-surface temperatures, prevents the surface layers from becoming sufficiently dense to sink and form a North Pacific Deep Water.

Modified after Marshall and Plumb (2008). Background map: copyright by Ron Blakey, Colorado Plateau Geosystems, Arizona, USA.

relatively low sea-surface temperatures. Paradoxically, therefore, in the North Pacific, a cool sea-surface prevents the surface layers from becoming sufficiently dense to sink and form a North Pacific Deep Water (Brown et al., 1989a).

In addition, the global circulation driven at its origin by the formation of North Atlantic Deep Water causes a chemical differentiation between the Atlantic and Pacific. As the originally nutrient-poor deep water flows southward in the Atlantic and eastward across the Indian Ocean to the Pacific, it is steadily enriched in nutrients derived from the rain of particulate organic matter sinking from the surface and dissolved in the deep ocean. The enrichment in total dissolved organic and inorganic carbon of the waters reaching the Pacific basin and resurfacing in upwelling zones impacts on the acidity of the water, and hence on the dissolution of carbonate. Calcium carbonate will more readily dissolve in a depth-dependent way in Pacific waters than in Atlantic waters (Brown et al., 1989b).

Scleractinian corals build their skeletons of aragonite, a metastable form of calcium carbonate that dissolves at shallower depths than calcite. The base of the saturated water mass in which scleractinian mound building corals (Lophelia pertusa, Madrepora oculata, etc.) can thrive is given by the aragonite saturation horizon (ASH).

The distribution of cold-water coral mound provinces identified so far in the modern ocean is plotted on a background of ASH depth in 1995 (Fig. 6a) (Orr et al., 2005; Guinotte et al., 2006). The vast majority of cold-water coral mound provinces plots in the seabed areas above a deep ASH (dark blue fields, ASH depth range 1000-2000 m or more), with a focus on the North Atlantic. Diversity contours for azooxanthellate scleractinians are added (Cairns, 2007). These contours confirm that the North Atlantic is a focus of diversity in azooxanthellate scleractinians in the Atlantic domain, though the highest diversity is still found in the SW Pacific. Guinotte et al. (2006) reported that the deepsea scleractinians found in the North Atlantic are bioherm-forming, robust and prolific, covering areas several square kilometers. In the Central to North Pacific, ASH depths largely range between 100 and $400 \mathrm{~m}$ (Fig. 6a, orange to yellow fields). North Pacific scleractinians tend to be found in solitary colonies and the region is dominated by octocorals (soft corals, stoloniferans, sea fans, gorgonians, sea pens) which use calcite to build their spicules and skeletons (Cairns and Macintyre, 1992). The only mound occurrence unequivocally documented on the eastern
North Pacific margin is the siliceous hexactinellid sponge mound province in the Queen Charlotte Basin, Canada (Conway et al., 2005).

The virtual absence of large cold-water coral mound provinces in the North Pacific and other parts of the global ocean hence can be simply explained by a chemical control on the mound-builders. An interesting observation in Guinotte et al.'s (2006) modeling of the decrease of seawater $\mathrm{pH}$ and aragonite saturation due to an influx of anthropogenic $\mathrm{CO}_{2}$ to the atmosphere is the robustness of the North Atlantic ASH depression. In a projection for 2080 , the North Atlantic mound provinces in water depth of 800 to $1000 \mathrm{~m}$ depth would still be at the threshold of aragonite saturation, while the ASH dramatically shallows in other seas (Fig. 6b). This remarkable robustness possibly argues for a conjunction of controls acting in concert in the North Atlantic, rather than a unique one. Fig. 7 illustrates some relevant current patterns in the North Atlantic Mound Basin. The mound provinces literally girdle the subtropical gyres. In their vertical distribution, mound provinces tend to cluster either right above the present-day base of the warm upper water masses, or just below. A number of observations are summarized below.

On the American margin of the North Atlantic, where surface waters reach depths, greater than on the European margin, the mounds of the Florida-Hatteras slope and Blake Plateau occur in depths from $440 \mathrm{~m}$ to $1300 \mathrm{~m}$ and are fully bathed by the Florida current, which merges with the Gulf Stream, the main component of the North Atlantic Current (NAC) in that region (Teichert, 1958; Stetson et al., 1962; Neumann et al., 1977; Reed, 1980; Mullins et al., 1981; Paull et al., 2000; Correa et al., 2012). The larger mounds described by Mullins et al. (1981) occur in the lower interval of this surface water layer, between 1000 and $1300 \mathrm{~m}$. Strong benthic currents are reported.

On the north-west European margin, west of Ireland, the mound provinces in Porcupine Seabight range in depth from 750 to $1050 \mathrm{~m}$ and are bathed by Mediterranean Outflow Water (MOW), which grades upward into Eastern North Atlantic Water (ENAW) at a depth between 800 and $700 \mathrm{~m}$ (White, 2007; Foubert and Henriet, 2009; Wheeler et al., 2011). Strong internal waves guided by the permanent thermocline have been reported and modeled in the depth interval of the mounds (White, 2007), which also coincides with an oxygen minimum zone (Freiwald, 1998). In Rockall Trough, cold-water coral mounds occur in a depth range of 600 to $1000 \mathrm{~m}$, within the lower interval of warm 

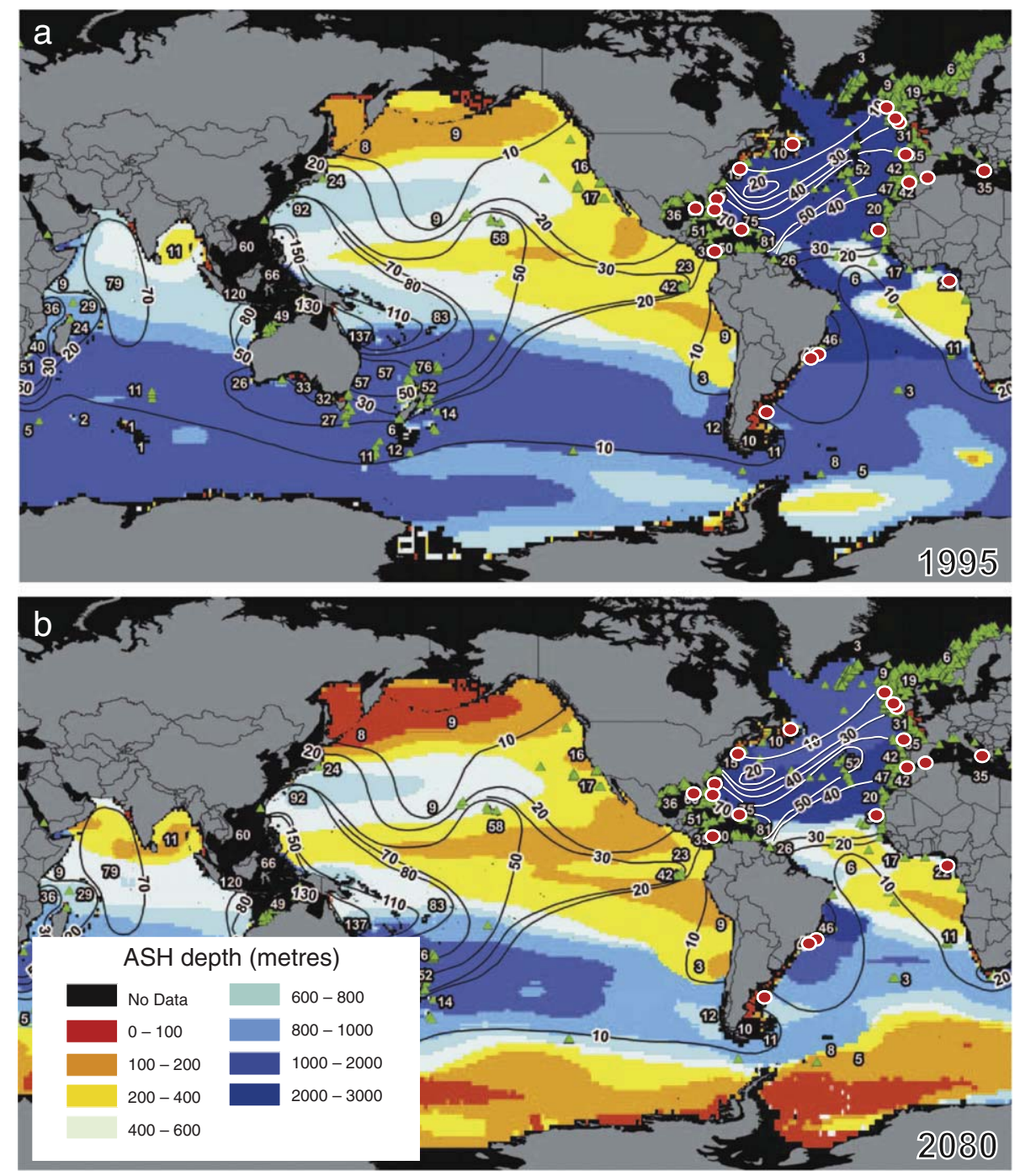

Fig. 6. a) The distribution of cold-water coral mound provinces identified so far in the modern ocean is plotted on a background of aragonite saturation horizon (ASH) depth (modified after Guinotte et al., 2006). The vast majority of cold-water coral mound provinces plots in the seabed areas above a deep ASH (dark blue fields, ASH depth range $1000-2000 \mathrm{~m}$ or more), with a focus on the North Atlantic. Diversity contours for azooxanthellate scleractinians have been added (modified after Cairns, 2007). b) A projection of ASH depth for 2080, modified after Guinotte et al. (2006), suggests the North Atlantic mound provinces in water depth of 800 to $1000 \mathrm{~m}$ depth would still be at the threshold of aragonite saturation, notwithstanding a dramatic global rise in the ASH.

and saline ENAW, overlying the cooler Labrador Sea Water (LSW) at some $1200 \mathrm{~m}$ (Mienis et al., 2007). Rockall Channel (Bonnin et al., 2006) and the Faeroe-Shetland Channel (Van Raaphorst et al., 2001) are sites of intense mid-slope resuspension by internal waves.

On the north-west African margin, the carbonate mounds on the Pen Duick Escarpment off Larache occur in water depths of 530 to $580 \mathrm{~m}$, in North Atlantic Central Water (NACW) containing several nepheloid layers, and overlying Antarctic Intermediate Water (AAIW) found at a depth of $600 \mathrm{~m}$ (Van Rooij et al., 2011). Further south, an elongated carbonate mound range occurs in Mauritanian waters at depths of 450 to $550 \mathrm{~m}$, over a linear extent of at least $190 \mathrm{~km}$ (Colman et al., 2005). Warm and saline Tropical Surface Water (TSW) overlies low salinity South Atlantic Central Water (SACW) down to $600 \mathrm{~m}$, where a sharp halocline marks the boundary with fresher AAIW (Stramma and Schott, 1999; Eisele et al., 2011). The SACW forms an oxygen minimum layer and is the nutrient-rich source of upwelling water in the region (Colman et al., 2005).

In the South Atlantic, cold-water coral ecosystems and elongated patches of deep-water coral mounds have been reported on the slopes of the Campos Basin, off Brasil, clustering between $570 \mathrm{~m}$ and $850 \mathrm{~m}$ within the upper horizons of the AAIW, right below the South Atlantic Central Water (SACW) (Viana, 1994; Viana et al., 1998). On the
Patagonian slope off Argentina, cold-water coral mounds occur mainly between 400 and $1000 \mathrm{~m}$ depth, in the basal horizons of the AAIW which flows in northward direction over the Upper Circumpolar Deep Water (UCDW) (Muñoz et al., 2012).

The already dynamically stratified North Atlantic basin is further stirred by oscillations at various frequencies. At the pace of the glacial-interglacial rhythm, shifts of polar fronts force north-south displacements of cold nutrient-rich intermediate waters and surface productivity (Frank et al., 2011). These shifts stimulate coral growth on the European margins in interglacial times (Dorschel et al., 2005; Roberts et al., 2006; Rüggeberg et al., 2007), and on the African margins in the arid times (Wienberg et al., 2010) that coincide with glacial conditions further north. Furthermore, at the pace of the North Atlantic Oscillations, the upwelling on the north-west African margin can be significantly enhanced (NAO + phases, Meincke, 2002).

A general observation is consequently that the deep carbonate mound provinces seem to closely fringe the roof of the intermediate to deep water masses of the present, dynamically stratified Atlantic Ocean. It should however be kept in mind that the large deep-water carbonate mounds in the Atlantic may well have been born over $2.5 \mathrm{Ma}$ ago (IODP Exp. 307, Kano et al., 2007) in a water mass architecture differing from the present one. On the east Atlantic margin, mound provinces 


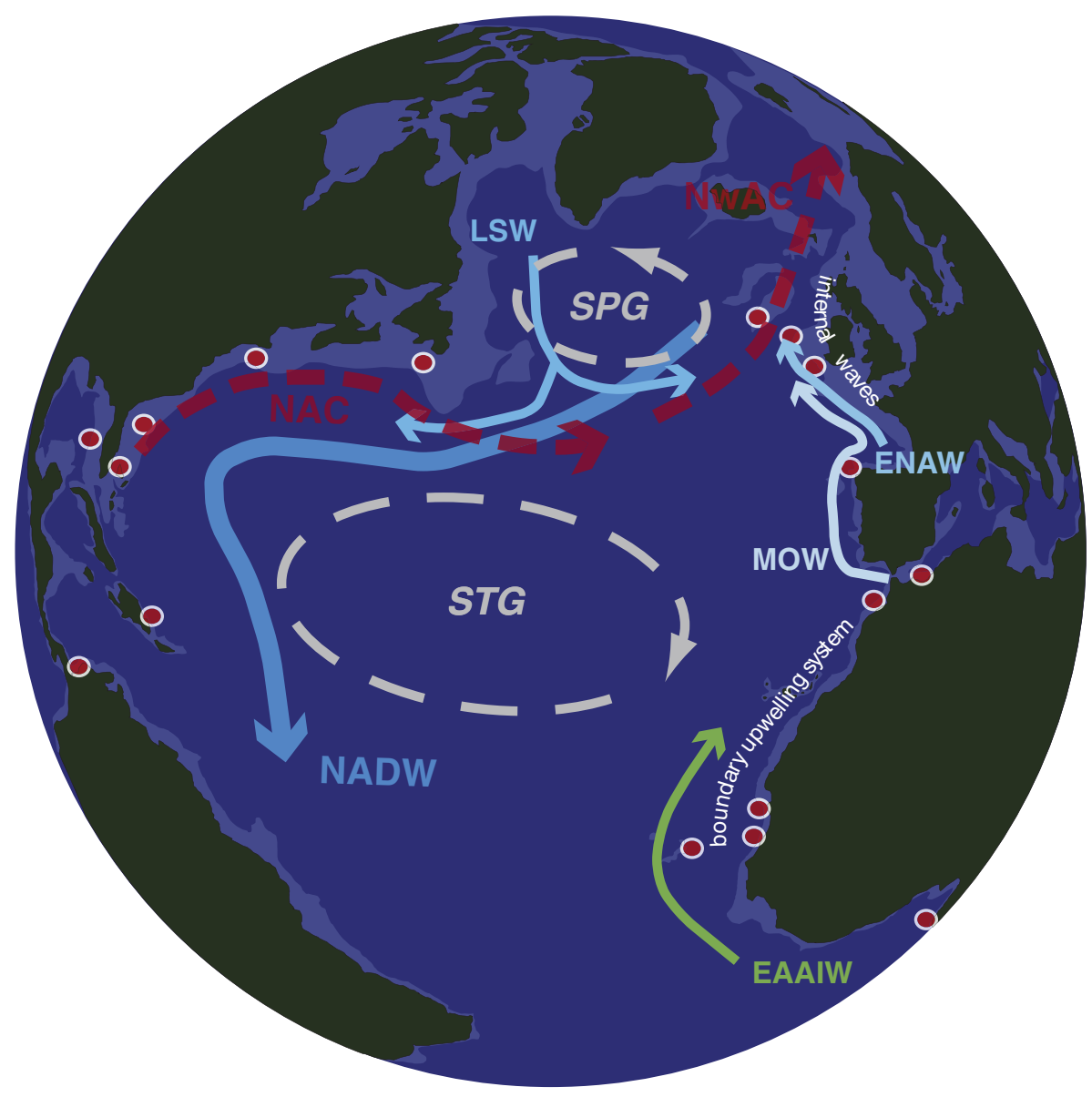

Fig. 7. Overview of surface, intermediate and deep water circulation, discussed in the description of the oceanographic setting of some main mound provinces in the North Atlantic Mound Basin. The mound provinces girdle the North Atlantic subtropical gyre system. On the eastern Atlantic margin, from Galicia Bank to the Shetlands, mound provinces occur in zones of intense mixing through internal waves. The Iberian margin and the African margin till $10^{\circ} \mathrm{N}$, south of Dakar, belong to the Eastern Boundary Upwelling Zone.

concentrate in the nutrient-rich, low-oxygen horizons either just above or just below the base of the surface circulation layer. These horizons are within the beat zone of internal waves guided along an interface with significant density contrast (Porcupine-Rockall basins), or in zones of upwelling. The vast and heterogeneous Eastern Boundary Upwelling System (EBUS) stretches along the Atlantic margin from the northern tip of Iberia at $43^{\circ} \mathrm{N}$ to south of Dakar at about $10^{\circ} \mathrm{N}$.

Interestingly, density stratification may also impact on the genesis of mounds in another way, by a control on the migration pathways of larvae of mound-building metazoans. Dullo et al. (2008) showed the importance of a narrow sea water density envelope for living Lophelia reefs.

Seen from an energy sourcing and energy processing perspective, the modern ocean's carbonate world essentially splits in two boundary layers, one at the top and one at the base of the upper ocean water mass, in which gyral circulation is forced by atmospheric dynamics. Incidentally, the classic open shelf to ramp cool-water carbonate facies, defined by Lees and Buller (1972) as "Foramol", might fit as a transitional facies.

The upper carbonate world directly thrives on light as a main source of energy: it is the domain of the Photozoan carbonates, confined by water depth and the penetration of light (James, 1997). In the mechanically stirred lower carbonate world, heterozoan mound-builder guilds directly forage on fluxes of nutrients, which percolate from the photic zone as pelagic rain, and/or get generated by in situ benthic processes, and/or rise from the lower compartment through deep-sourced upwelling, although not all authors concur with this view (Lees and Miller, 1995). While the lower carbonate world appears to be commonly coupled to a major interface between water masses, it is not confined in space. Deep water mounds can grow in a virtually unconstrained way, to the dimension of giants. Yet, the subtle functioning of the working parts that underpins the performance of the mound engine remains to be elucidated.

Size-wise, Paull et al. (2000) already speculated that the area covered by the deep-water mounds in the Straits of Florida and inner Blake Plateau might be greater than their better known shallow counterparts in the region. This statement is certainly valid on the eastern margin of the North Atlantic. The cool, dark and turbulent carbonate world of the deep Atlantic might well outclass the restful surface carbonate factory, wrapped in warmth and displayed in shimmering colors.

\section{New views on old oceans: a case for a Paleo-Tethys conveyer belt?}

A comparison of the present distribution of cold- and warm-water carbonate factories with some relevant scenery of the past may provide inspiring clues to the wider perspective on oceanic controls. In a way, a plot of warm- and cold-water carbonate basins in the modern ocean would nicely complete the compilation of Flügel and Kiessling (2002) for Phanerozoic times, which ends at Time Slice 32, as it would represent the missing Time Slice 33 (2.5 Ma - present). In coherence with earlier statements (Section 8), there is a logic to compare the present basin configuration of deep carbonate mound provinces - Time Slice 33 - with that in the Carboniferous to Permian, as illustrated by Golonka's (2002) Time Slices 11 to 15 (in Kiessling et al., 2002) (Fig. 8). Quite a few characteristics of climate and ocean in the Carboniferous already do match Late Cenozoic environmental conditions (sea 

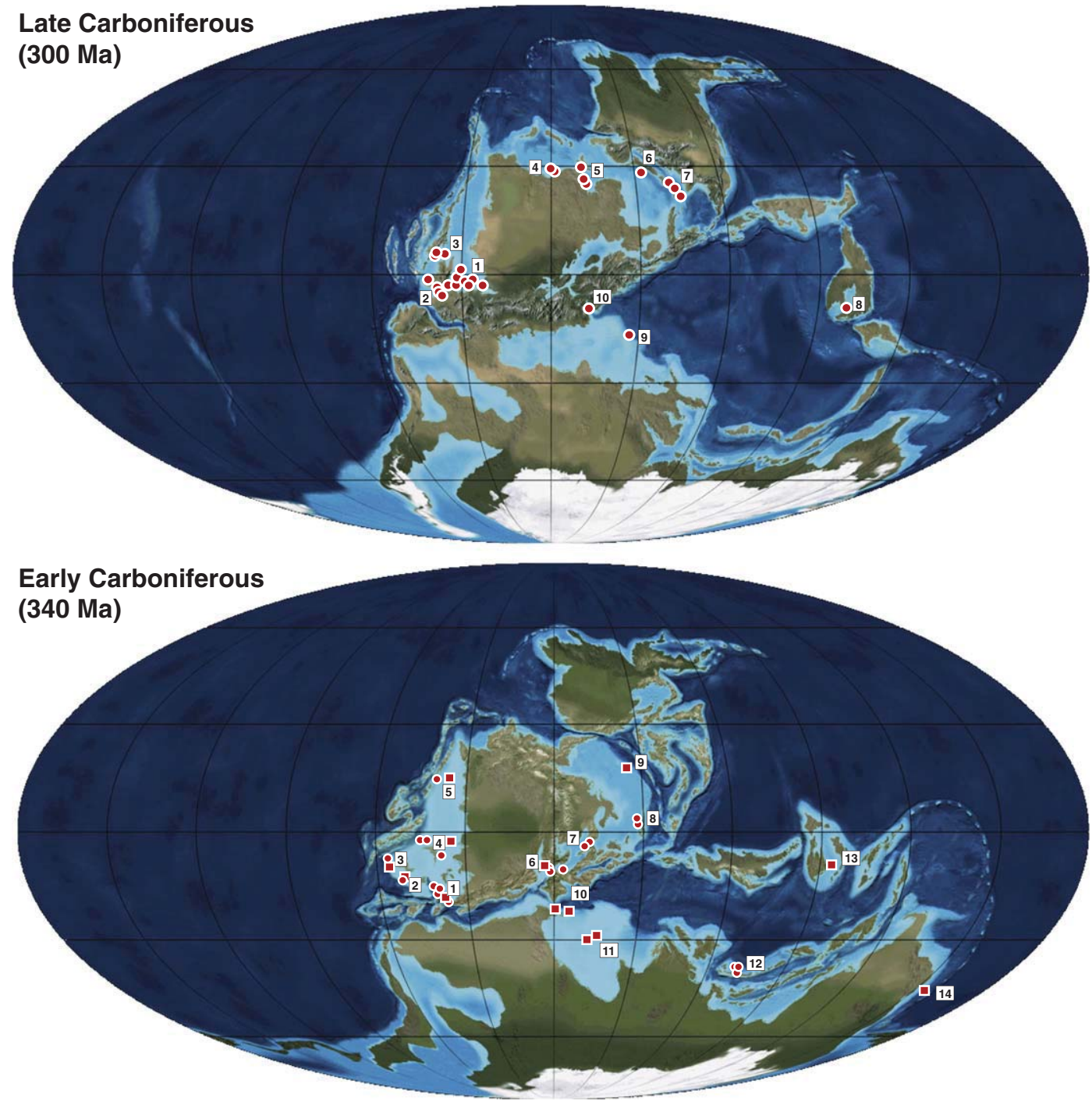

Fig. 8. (Top) Mound distribution of the Late Carboniferous (Bashkirian-Kasimovian) plotted on a Late Carboniferous (300 Ma) reconstruction. Geographic distribution of biogenic mounds from Wahlmann (2002). Locality numbers on map refer to following regions: 1. Illinois and Kansas; 2. Arkansas, Oklahoma, Texas, New Mexico, and Arizona; 3 . Colorado and Utah; 4. Canadian Arctic Archipelago; 5. northeast Greenland and Spitzbergen; 6. Timan to Subpolar Urals, Russia; 7. central Urals to Kazakhstan; 8. Guizhou, South China; 9 . Serbia; and 10. Cantabrian Mountains, northern Spain. Paleomap provided by Ron Blakey, NAU Geology. (Bottom) Mound distribution of the Early Carboniferous (Tournaisian-Visean) plotted on an Early Visean (340 Ma) reconstruction. Geographic distribution of Tournaisian (circles) and Visean (squares) mounds from Webb (2002). Locality numbers on map refer to following regions: 1. Indiana, Kentucky, Tennessee, Missouri, Oklahoma, Arkansas; 2. New Mexico; 3. California; 4. Montana; 5. Alberta, Canada; 6. Great Britain, Ireland; 7. Belgium, Germany, Poland; 8. middle Urals to North Caspian Depression, Russia, northwestern Kazakhstan; 9. Polar Urals, Pechora, Russia; 10. western Algeria and Morocco; 11. Lybia, eastern Algeria; 12. Afghanistan; 13. Guangxi, Guizhou, South China; and 14. New South Wales, Australia.

Background maps: copyright by Ron Blakey, Colorado Plateau Geosystems, Arizona, USA.

level, $\mathrm{CO}_{2}$ concentration, carbonate saturation trend, high amplitude eustatic sea-level changes driven by the waxing and waning of continental ice sheets), so, what about the ocean basins? In Carboniferous to Permian times, the great tropical oceanic basin of the Paleo-Tethys developed, recessed within the continent of Pangaea to the west, which in many aspects evokes the western Atlantic Ocean margin, and girdled by a string of micro-continents to the east. This string remarkably mirrors the present Indonesian archipelago, a gateway between Pacific and Indian Ocean circulations. Between Gondwana and the AvaloniaBaltica assembly, the Rheic Ocean narrowed. High to the northeast, between Laurentia-Baltica and Siberia, the Ural Seaway connected to high-latitude seas. In a way, the Carboniferous Paleo-Tethys resembles in its confines a compound Atlantic-Indian Ocean system. Fig. 8 (top) and (bottom) represent the distribution of major reef provinces respectively in the Late Devonian to Early Carboniferous and in the Upper Carboniferous. Fig. 8 (top) shows Famennian to Serphukovian reefs projected on a Visean paleogeography (340 Ma, Webb, 2002). Fig. 8 (bottom) shows Bashkirian to Kasimovian reefs projected on a paleogeography at the end of the Carboniferous (300 Ma, Wahlmann, 2002).

Not only the configurations of the Atlantic and Paleo-Tethys domains present some remarkable common traits, but also the history of both oceans shows interesting parallelisms. As the Panamian Gap closed some $5 \mathrm{Ma}$ ago, separating the Atlantic and Pacific oceans, the intensification of the Gulf Stream may have triggered the glaciations of the northern hemisphere, about 2.7 Ma ago. The encroaching of the Armorican and Iberian assembly on the Rheic Ocean floor in the Early Carboniferous, which finally closed and separated the last realms of the Rheic Seaway from the widening Paleo-Tethys Ocean, may have triggered the onset of the large Gondwana glaciation, in the Serphukovian (330 Ma) (Salzmann, 2003; Roscher and Schneider, 2006).

As the Rheic seaway closed in the equatorial realm, warm surface waters of the Paleo-Tethys engulfed in the northern seaway. It is tempting to speculate that an underflow of boreal waters could have cascaded in return in the Paleo-Tethys, as happens in the northern Atlantic today, 
potentially giving rise to water mass differentiation and the development of a conveyer belt, mirroring recent Atlantic and global conditions. On the margins of this seaway, cold water carbonates developed, from the Canadian Arctic, North Greenland and Svalbard-Barents Sea regions (Beauchamp and Desrochers, 1997; Stemmerik, 1997; Colpaert, 2007; Colpaert et al., 2007) over the Ural foredeep, down to the Pre-Caspian basin. The basal sequences of the giant Karachaganak carbonate buildup of northern Kazakhstan, one of the world's largest gas condensate reservoirs (Elliott et al., 1998), developed in the Visean to Serpukhovian on the margin of this boreal seaway. The intensification of continental glaciations from the Serpukhovian onwards would have resulted in a change in ramp geometry (Read, 1998). This impact argues for basinwide changes in ocean circulation, from the surface to the depths of the Paleo-Tethys, paced by the waxing and the waning of the ice sheets. The Paleo-Tethys mirrors the bi-polar control on deep waters of the Atlantic, with sources of cold bottom waters both in the north and the south. The upper sequences of the Karachaganak build-up developed in Permian times (Elliott et al., 1998), when the Ural seaway started to close and the boreal waters got covered by sea ice. Highlatitude warm surface water deposition of carbonate in the Carboniferous and Early Permian gradually shifted to cool- and cold-water deposits in the Late Permian. Beauchamp and Baud (2002) hypothesized a thermohaline circulation and upwelling on the western margin of Laurentia-Baltica in the Panthalassa domain, leading to a shift to biosiliceous deposition, the Permian Chert Event. This circulation came to termination at the end of Permian times. James et al. (2009) documented three discrete periods of Permian deglaciation (Late Sakmarian, late Arkinsian and Wordian) in a Permian high-latitude, subpolar carbonate depositional realm in Queensland, Australia, and demonstrated a strong parallelism with coeval high-latitude carbonate deposition in the northern hemisphere.

The point made here is that, besides well-documented and vast carbonate factories in low-latitude, warm-water and shallow seas, both in the Carboniferous Paleo-Tethys and the modern Atlantic, giant mounds may have thrived in deeper waters of a compartmentalized ocean. In the Paleo-Tethys, mixing processes must have occurred at the boundary between an upper water mass, stirred by strong subtropical gyres, and deep water masses featuring a thermohaline circulation driven by glacial dynamics, as is the case in the Atlantic. Independently, investigators of Early Carboniferous (Stanton et al., 2000) and of Quaternary mounds (White, 2007) have inferred that internal waves guided by ocean stratification could have enhanced such mixing processes, thus acting as a possible control on deep mound genesis.

If deep mounds and their adjacent sediments do offer a window on deep water dynamics, vast opportunities open for integrated, largescale comparative studies and modeling, where academic and industrial research can meet. The deepening insights acquired in the coupled ocean/climate dynamics of the modern ocean may soon, when confronted with the vast data base of industrial research on the PaleoTethys margins, elucidate some fundamental keys to deep-water carbonate factories. Revisiting the world of Paleo-Tethys deep-water mounds may significantly boost insights in the complex and fascinating world of a hitherto poorly documented Paleozoic deep circulation system, and possibly shed light on a great Carboniferous Conveyer Belt.

\section{From the ocean basin scale to the regional scale: the role of em- bayments, banks and gateways}

The Waulsortian mound population and the recent mound distribution display each a remarkable singularity or 'hotspot'. Krause et al. (2004) tentatively quantified the Waulsortian mounds of the Shannon Basin, where the total thickness of the Waulsortian Mound Complex reaches more than $900 \mathrm{~m}$, and the Midland-Dublin Basin, with a thickness of more than $500 \mathrm{~m}$. Counts ranged between $2.300\left(1 \mathrm{~km}^{2}\right.$ grid cell) and $21.000\left(0.33 \mathrm{~km}^{2}\right.$ cell size). Counts of recent giant mounds from the multibeam coverage of the Irish Seabed Survey (Dorschel et al., 2010) and from 3D seismic data volumes in Porcupine Basin (Huvenne et al., 2007) yielded a similar range. Lees and Miller (1995) showed how the mounds in the Shannon and Midland-Dublin Basins appear to have formed offshore in the deeper water of an approximately $200 \mathrm{~km}$ wide and $300 \mathrm{~km}$ deep embayment, a size strikingly similar to Porcupine Seabight. A comparative modeling of the energy enhancement through trapping and resonance of internal waves in such basin geometries may yield interesting insights.

This observation highlights the importance of regional paleo-topography, in particular where internal waves may play a role in mixing processes. Embayments such as the Shannon and Midland-Dublin Basin and Porcupine Seabight, banks such as Little Bahama Bank, Rockall Bank, Porcupine Bank and Galicia Bank, and straits such as Florida Strait, the Rifian Corridor, the Betic Corridor and Rockall Basin prove privileged sites for mound growth.

\section{Mounds as paleo-environmental recorders}

Man's capacity to read the record of deep-water mounds in terms of water mass properties has impressively progressed in recent years. Paleo-environmental research boosted by hundreds of oceanic cruises and vast programs of ocean coring and drilling, paralleled by ice coring, has turned a crucible for a wealth of new proxy tools, which help to better constrain paleo-temperatures, paleo-density, paleo-salinity and paleo-pH. New tracers allow tracking circulation patterns, and this opportunity no doubt amplifies with recent programs like GEOTRACES, aiming to improve the understanding of biogeochemical cycles and large-scale distribution of trace elements and their isotopes in the marine environment. Very-high resolution seismic reflection profiles reveal the dynamic nature of the mound environment, frequently consisting of contouritic deposits (Van Rooij et al., 2003, 2009). Nepheloid plumes of particles and nutrients re-mobilized by impacting internal waves or transported from river sources are imaged in the modern ocean, and their signals identified in the mound record. The challenge is now to proceed from these new insights and tools, developed in the modern ocean, to deeper time, in a stepwise mode, allowing a close control on levels of uncertainty. The challenge is grand, as the track follows an evolutionary tree of Life, and physico-chemical processes of diagenesis may have blurred original signals. Promising analyses have already been made on Lower Mississippian rocks (Stanton et al., 2000, 2002). New tools have however been developed, including molecular ones, which increase the power of paleo-environmental analysis. Clumped-isotopes (isotopologues of $\mathrm{CO}_{2}$ ) provide a powerful tool in reconstructing temperatures of carbonate precipitation, potentially deep in Paleozoic times (Eiler, 2011), as long as the message has not been blurred by diagenetic processes, in particular dolomitization.

The coring of Challenger Mound in Porcupine Seabight with a recovery rate close to 100\% in IODP Exp. 307 and the analysis of the core record at centimeter-scale resolution has revealed the temporal pattern of sedimentation, including astronomic controls (Foubert and Henriet, 2009). A minute analysis of ice-rafted debris has shed light on a stunning record of all glacial advances on the Irish mainland. Where the glacial record on land did not extend further than the two last episodes, all earlier traces having been erased by subsequent ice sheets, the deepwater mound succession faithfully recorded all ice rafting phases and allowed back-tracking the origin of the sediment load (Thierens et al., 2012).

The record of paleoenvironment in carbonate mounds may however be interrupted by significant hiatus, ranging from $0.6 \mathrm{Myr}$ in Challenger Mound (from 1.67 to $1.03 \mathrm{Ma}$, Kano et al., 2007) to at least $33 \mathrm{Myr}$ in the Karachaganak carbonate buildup (Elliott et al., 1998). The latter gap spans the whole Late Carboniferous between Late Serpukhovian and the beginning of the Asselian (Lower Permian). If mound-building is linked to processes bound to an interface between water masses, it is tempting to read such major gaps as the expression of significant shifts in water masses, unless bound to a change in water chemistry 
stratification (ASH depth) which impacted on mound-builders. By the same token, the rebound of mound growth after such major gaps can form an eloquent demonstration of the resilience of giant carbonate mounds, when a suitable architecture of controlling water masses and/or chemical stratification is restored.

Fossil mounds have so far largely been sampled in a fragmentary way, on occasional outcrops, on quarry faces and in industrial wells. The successful practice of continuous coring and high-resolution sampling, generalized in modern mound research in the marine environment, calls for extension to fossil mounds on continents, with comparable analytical protocols wherever applicable, to fully exploit the power of comparative studies.

\section{Mounds at the cross-roads of external and internal fluxes of mat- ter and energy}

Upwelling is not a sufficient explanation for mound growth, as it functions at a scale that should promote broadly distributed carbonate production, rather than growth of individual mounds (Lees and Miller, 1995; Stanton et al., 2000). Upwelling may be a means to increase regional phytoplankton productivity, but it is not clear how it can be focused to cause microbial carbonate mud production at the local scale and at rates vastly greater than on the adjacent sea floor.

A similar caveat could be stated about internal waves, and in the modern ocean, about the distribution of the main metazoan mound builders, cold-water corals. All of these controls occur and operate at scales, difficultly matching the focused occurrence of clusters of giant mounds. Deep-water mounds typically are clustered in provinces, razor-sharply delineated from the adjacent seafloor (Fig. 9). On the European margin, a targeted search for mound provinces between Porcupine Seabight and the Gulf of Cadiz, systematically screening formerly prolific occurrences of cold-water corals (Le Danois, 1948), proved so far unsuccessful. Only some isolated mounds were spotted on the slopes of Galicia Bank. Yet, Mediterranean Outflow Water flows all along those margins (Hernández-Molina et al., 2011), cold-water corals are ubiquitous (Reveillaud et al., 2008) and internal waves have been documented at a vast scale in the Gulf of Biscay (New, 1987).

External controls are consequently not a sufficient explanation for mound occurrences and mound growth. From the beginning of the vast European research on deep-water carbonate mounds initiated in the late nineties, a balanced attention has been paid to both potential external and internal controls, to external fluxes of energy as well as to internal, sub-seafloor fluid flow. The latter interest arose in parallel with the emerging research on the sub-seafloor hydrosphere and the deep biosphere. The results of this research could make the object of another overview paper, but they can be summarized for the present purpose in a few statements.

First, prior to burial, a positive relief on the seafloor of any size, from a small hummock or ripple to a giant mound, is the seat of convective transport, coupled to the bottom currents. The coupling of surface (Navier-Stokes) and sub-surface (Darcy) flow across an interface such as a river bed or a rippled sediment surface is already well studied, both theoretically and experimentally (Thibodeaux and Boyle, 1987). It rules for instance pollutant transport, oxygen and nutrient fluxes across the seabed. In mounds, such transport is an important factor of early diagenesis. Pirlet et al. (2010) demonstrated that a bottom current-induced convective flow of oxidizing fluids in the shallow subsurface of a mound led to the formation of authigenic gypsum and to an early lithification of sediments close to the sediment-water interface. Modeling of full-mound flushing by Depreiter (2009) can explain the observed removal of a significant carbonate fraction, mainly aragonite, from recent mounds. Such process underpins the vision of mounds as open diagenetic systems, prior to burial (Foubert and Henriet, 2009).

Second, where giant carbonate mound provinces occur, surface expressions of deep-sourced, advective fluxes of geofluids have been repeatedly reported, in proximal or in remote position, including pockmark fields (Porcupine Seabight, Van Rensbergen et al., 2007), mud volcanoes (Alboran Sea, Comas et al., 2009; Gulf of Cadiz, Van Rensbergen et al., 2005), sulfate-methane transition zones, both within a mound (Alpha Mound, Pen Duick Escarpment, Morocco, Maignien et al., 2010) and below a mound (Challenger Mound, IODP Exp. 307, Frank et al., 2010). In the latter setting, advanced basin modeling shows how deep fluids can migrate along stratigraphic pathways, to surface in the Belgica Mound province where Challenger Mound was drilled (Naeth et al., 2007). The Mauritanian mounds occur in basins of active hydrocarbon exploitation (Colman et al., 2005), and commercial or noncommercial hydrocarbon accumulations have been reported below the mound provinces off Larache and off Melilla. In the fossil record, associations of mounds and internal, quasi-contemporaneous fluid flow have also been documented, and the proposed Heritage Route in Morocco features some outstanding examples (Belka, 1998; Mounji et al., 1998; Peckmann et al., 1999; Belka and Berkowski, 2005; Peckmann et al., 2005; Cavalazzi et al., 2007).

In none of the recent mounds cored so far, however, neither on the Irish margin nor on the Morocco margin, a direct control of methane on the mound build-up process itself could be conclusively proven. The role of internal fluid flow in giant mounds seems to be subtle, acting more on diagenesis than on genesis. A three-phase model has been proposed for the development of mounds on the Moroccan margin, comprising coral colonization, sediment baffling and fluid seepage affecting the initial structures by diagenetic processes, resulting in cold-

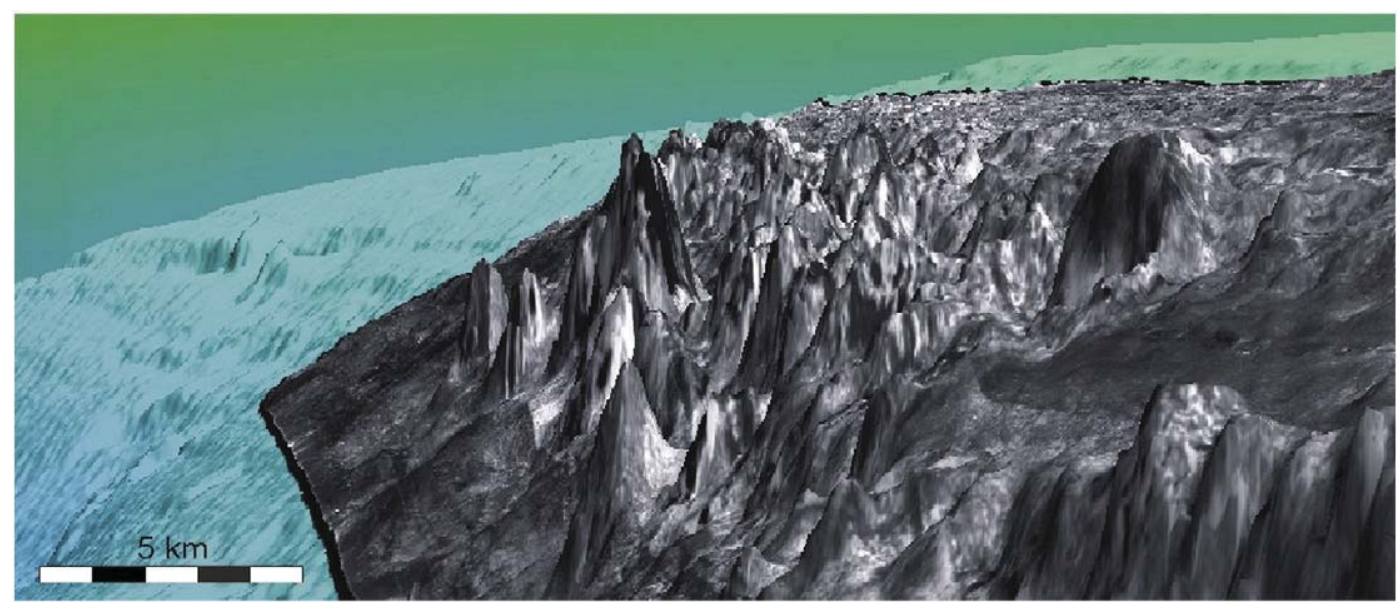

Fig. 9. Rockall Bank Mound Province (Mienis et al., 2006). 
water coral dissolution and carbonate precipitation (Foubert et al., 2008; Foubert and Henriet, 2009). The Alpha Mound on Pen Duick Escarpment, featuring a shallow zone of anoxic oxidation of methane (AOM) (Maignien et al., 2010), comprises up to 40\% of microbial dolomite (Templer et al., 2011; Wehrmann et al., 2011; Pirlet et al., 2012).

An interesting experiment would be to drill a sequence of mounds from exposed ones to recently buried ones, to track in particular the diagenetic expression of the switch from open diagenetic system (the "mound flushing" stage of exposed mounds) to encapsulation, both in a proven pathway of advecting fluids (Melilla mound province, Alboran Sea, Morocco, Comas et al., 2009) and in a setting, possibly not affected by migrating fluids (Magellan - Perseverance mound suite, Porcupine Seabight, Huvenne et al., 2007; Pirlet et al., 2010).

What can be stated so far from observations both in Porcupine Seabight and on the Atlantic and Mediterranean Moroccan margins, is that major mound provinces seem to concentrate at the crossroads of fluxes of energy of oceanic and of deep subsurface origin (Van Rooij et al., 2011).

\section{Morocco: a room with a view}

The confrontation of observations and insights between researchers of the modern carbonate systems and those of the fossil record calls for a common forum and stage, a broadband field laboratory, which can be turned into a meeting place and reference site. A most remarkable and accessible spectrum of carbonate factories, which strikingly illustrate the successive phases of rise and demise of carbonate mounds over the total span of Phanerozoic times, is offered in Morocco.

Morocco indeed occupied repeatedly through Phanerozoic times a privileged position, a room with a view on key oceanic basins and gateways, where major reef and mound provinces developed. Meanwhile, it migrated through all climatic belts from boreal waters, across the equator to its present latitude (Fig. 10). From Cambrian to Ordovician times (500 to $480 \mathrm{Ma}$ ), when the huge island archipelago Avalonia was wrenched away from the edge of the Gondwana megacontinent, until

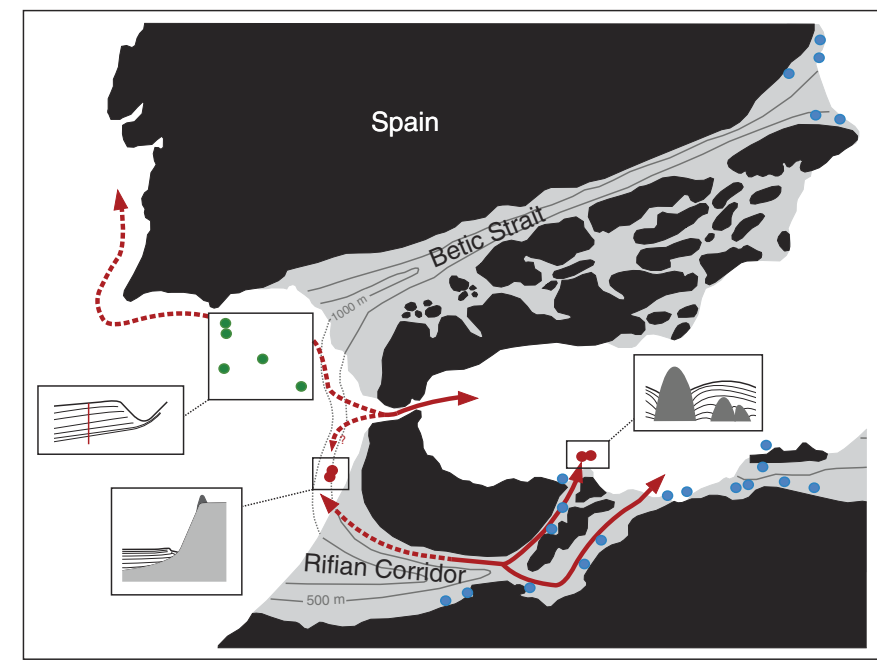

Fig. 11. Detail of the dual Miocene gateway between the Atlantic and the Mediterranean, comprising the Betic Corridor and the Rifian Corridor. Map modified after Benson et al. (1991). Tortonian mound locations (blue dots) after Perrin and Bosellini (2012). The drill sites of IODP Exp. 339 (Mediterranean Outflow) (green dots) document the environmental significance of the Mediterranean Outflow Water and its global implications.

deep in the Devonian, Morocco was located on the high-latitude, southern margin of the Rheic Ocean. In the continued wrenching of the Gondwana margin, Morocco eventually lost the Meguma Terrane, which around $350 \mathrm{Ma}$ in the Early Carboniferous collided with the Avalonia margin of Laurentia to form the present submarine Scotian Bank, next to Grand Bank of Newfoundland (Redfern, 2000). In the Carboniferous, the Moroccan margin of Gondwana kept facing the eastern section of the moribund Rheic seaway, which definitively would close when the Armorican and Iberian assembly east of Morocco encroached on the

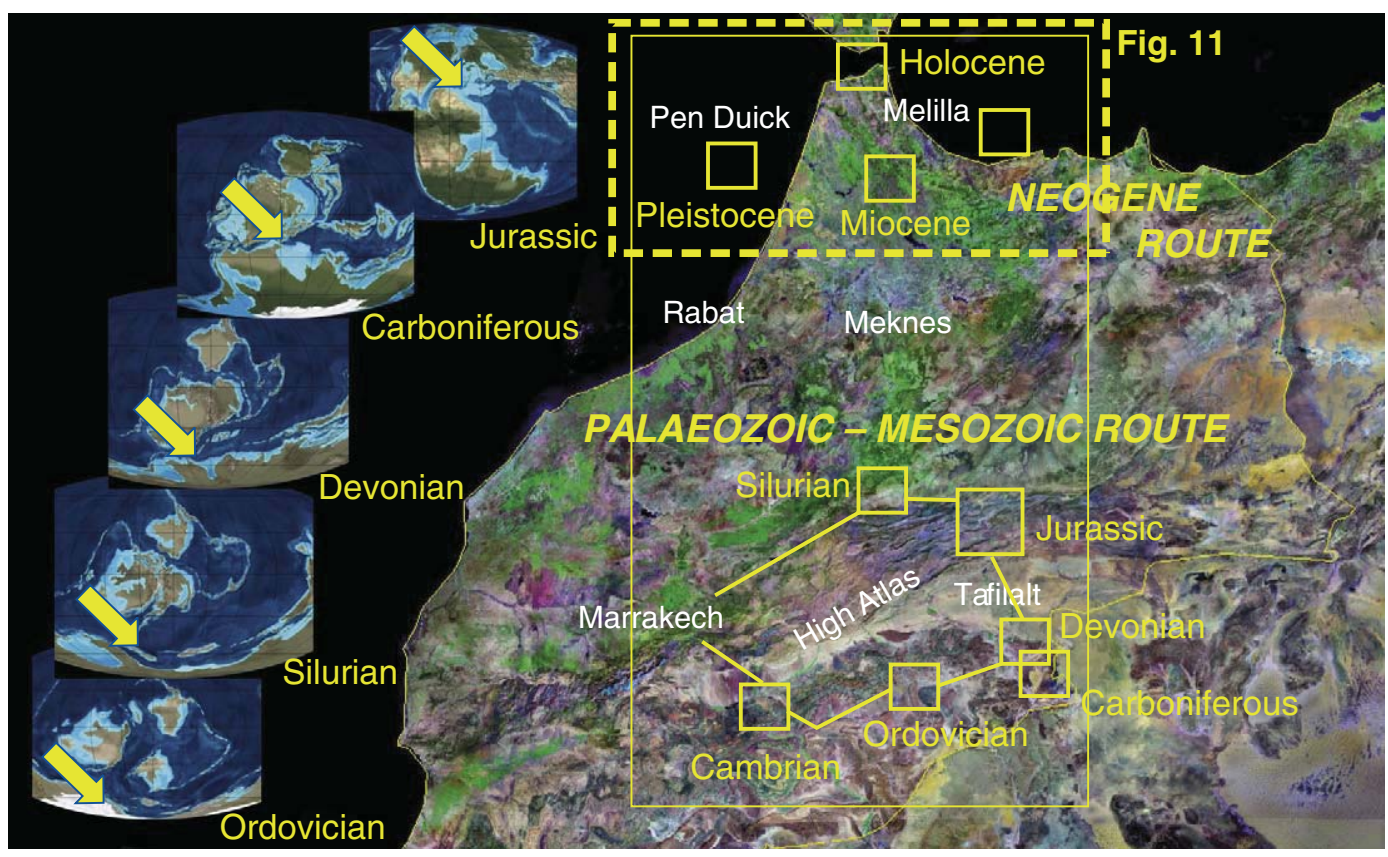

Fig. 10. Preliminary outline of a proposed mound Heritage Route in Morocco. The route segment circling the High Atlas encompasses outstanding examples of Paleozoic to Mesozoic mound sites. The route segment centered on Gibraltar encompasses the Miocene Rifian and Betic Corridors, flanked by the offshore Pen Duick and Melilla mound sites, focus of oceanographic research (detail on Fig. 11).

Paleomaps: copyright by Ron Blakey, Colorado Plateau Geosystems, Arizona, USA. Morocco background satellite image: copyright Geology.com 
Rheic Ocean floor to finally dock with Laurentia-Baltica, in the great continental collision known as the Variscan orogeny (350 to $286 \mathrm{Ma}$ ).

The Jurassic mounds of the High Atlas interestingly document the switch from Tethyan to Atlantic influence between Early and Mid Jurassic, after Morocco and Nova Scotia had started to drift apart. The recent mounds off Melilla in the Alboran Sea and off Larache on the Atlantic margin stand as sentinels on either side of the Rifian corridor (Fig. 11), which together with the Betic corridor in the north formed the gateways between Mediterranean and Atlantic, prior to the onset of the Messinian event. The Rifian corridor hosts a variety of Tortonian (Late Miocene) coral reefs (Perrin, 2002; Perrin and Bosellini, 2012). As to the present Gibraltar Strait, it is a hotspot of cold-water coral ecosystems (Álvarez-Pérez et al., 2005).

\section{The Moroccan Mound Heritage Route}

The October 2011 COCARDE workshop in Rabat and the subsequent field seminar in the High Atlas and Eastern Anti-Atlas surveyed significant sections of a mound route, which - when properly documented may qualify for a UNESCO recognition as World Heritage. The UNESCO World Heritage Convention indeed allows the recognition and preservation of outstanding examples representing major stages of Earth's history, including the record of Life, significant on-going geological processes in the development of landforms, and significant geomorphic and physiographic features (UNESCO, 2008). The Jurassic Coast of Dorset and East Devon is an example of a carbonate factory already recognized as UNESCO World Heritage Site (Brunsden, 2003), and the application of the Danish Stevns Klint Danian bryozoan mound site (Damholt and Surlyk, 2012) is under evaluation.

Fig. 10 shows an initial concept. A southern circuit circling the High Atlas and the Eastern Anti-Atlas massives between the valleys of the Ziz and the Draa comprises the interesting stromatolite series of the earliest Phanerozoic times in the Draa valley, the small but intriguing mounds of the glacial world of the Upper Ordovician of Eastern Maider north of Alnif (Hamoumi, 1999), a Silurian cold-seep mound of the Meseta domain between Mrirt and Azrou in the Middle Atlas (Barbieri et al., 2004), the famous Early Devonian Kess Kess mounds of the Hamar Laghdad Ridge in the Eastern Anti-Atlas (Fig. 12; Brachert et al., 1992; Belka, 1998; Aitken et al., 2002) and the exhumed underwater scenery of the Visean mounds with Waulsortian facies of the Zrigat Range (Fig. 13; Wendt et al., 2001), between the giant dunes of Erg Chebbi east of Merzouga and the Algerian border. Where the route further follows the gorge of the Ziz between Errachidia and Midelt, mound sequences of the Tethys realm from Early Jurassic (Sinemurian) and mounds of Atlantic signature from Mid Jurassic (Bajocian) are exposed in a spectacular way (Ait Addi, 1998; Neuweiler et al., 2001; Chafiki et al., 2004). North of Fez, the route crosses the former Rifian corridor with its Miocene reefs. In an appropriate setting, a visitor's center could further evoke the two major mound provinces that form the focus of modern mound research on the Moroccan margins: the Pen Duick Escarpment mounds off Larache on the Atlantic margin, and the Melilla mound province in the Alboran Sea, the region that possibly gave birth to the name "reef". This northern sector exemplifies mound development and environmental controls in the recent (NeogeneQuaternary) ocean.

A Moroccan mound route offers an attractive added value of cultural and societal relevance. It extends the routes of the Almorávides and the Almohades in Andalusia, identified as Grand Cultural Itinerary of the Council of Europe, across Gibraltar, to the imperial cities of Fez and Marrakech, which already enjoy the status of UNESCO World Heritage. Where the route branches through the High Atlas between Midelt and Errachidia, it follows the narrow gorge of the Ziz that was the umbilicus between the Al Andalus world and Sijilmasa, the legendary caravanserail that for centuries acted as the turn-table of the Saharan trade routes of gold and slaves. The Tafilalt region, where the most spectacular Paleozoic mound provinces are found, is a true little Mesopotamia, cradle of the Alaouite dynasty. A vintage "Route Royale des Monts Carbonatés du Maroc", as introduced in the COCARDE 2011 Workshop in Rabat, can take shape.

\section{Epilogue}

In the mid-nineteenth century, an iconic cruise - the voyage of the Beagle - sparked the first comparisons between modern warm-water coral reefs and possible examples from the fossil record. Shortly after the publication in 1878 of the French translation of Charles Darwin's "The Structure and Distribution of Coral Reefs", Eduard Dupont (1881) highlighted the analogy between the Keeling Atoll, described in detail by Darwin, and the Devonian "Atoll of Roly" in South Belgium, some hundred years later to be described as mud mounds by Monty et al. (1982). By those years, the technique of microscopical petrography, pioneered by Henry Clifton Sorby in Scotland (1858), had spread over the continent to develop soon into a powerful geological tool for reef research, adding to paleontology. For over a century, the study of carbonate rocks could thus largely build upon concepts of microfacies

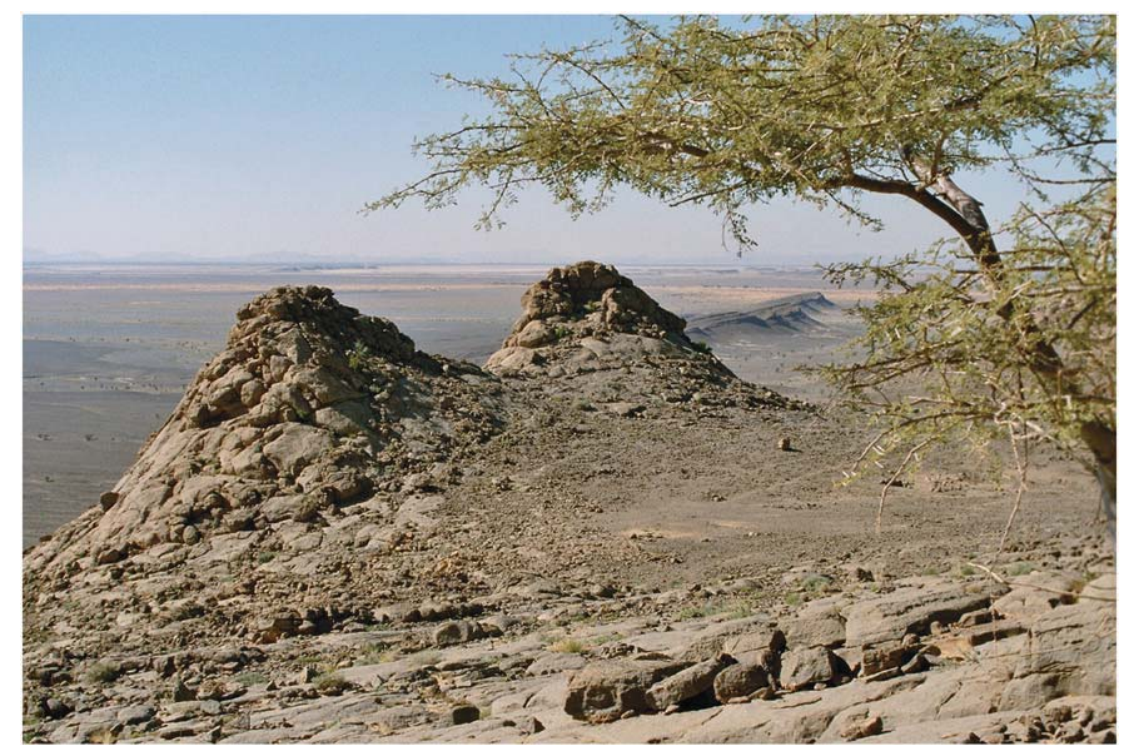

Fig. 12. The Devonian "Kess Kess" mounds of the Hamar Laghdad, Tafilalt, Morocco (picture: J.P. Henriet). They reach up to $30 \mathrm{~m}$ high. 


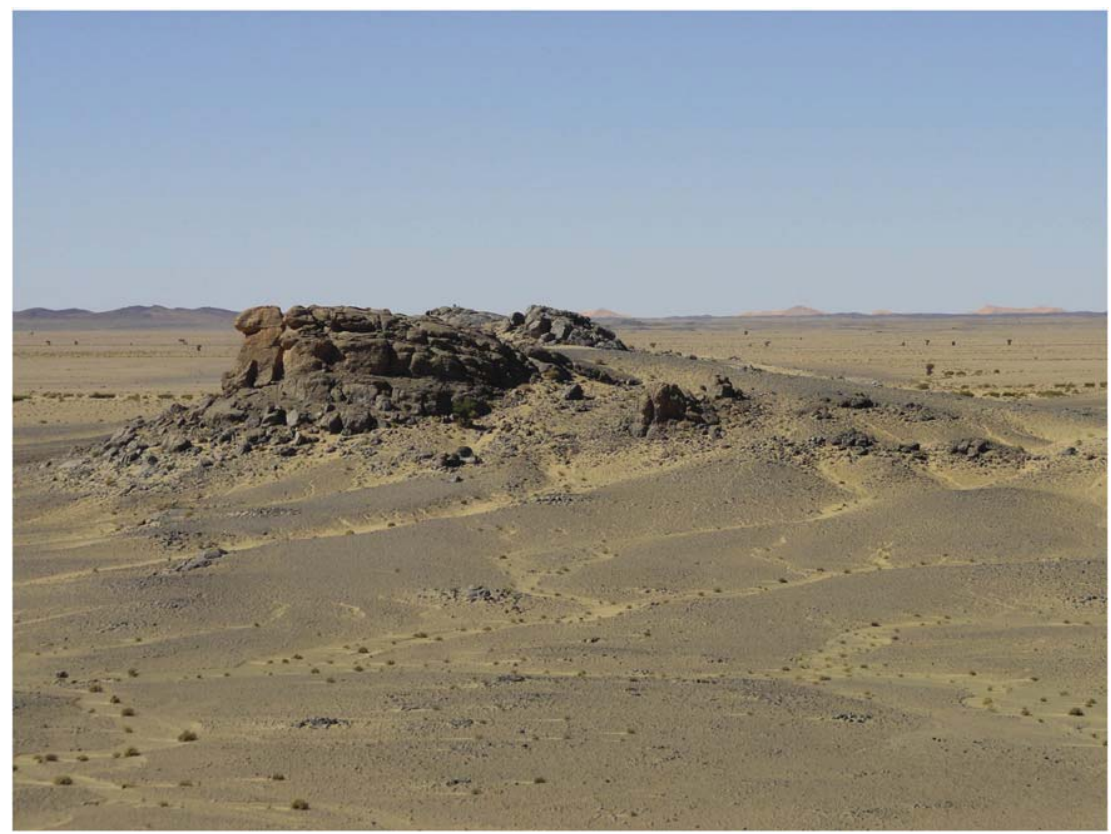

Fig. 13. The Carboniferous "Waulsortian" mounds of the Zigrat range, Tafilalt, Morocco, some $30 \mathrm{~m}$ high. (Picture: A. Rüggeberg).

and microfabric, applied in various carbonate classification schemes (Wilson, 1975; Flügel, 2004).

Again a century after Dupont's (1881) paper, Mullins et al. (1981) described modern deep-water coral mounds north of Little Bahama Bank, and spurred comparison with deep-water coral bioherms in the fossil record. When Hovland et al. (1994) reported deep carbonate build-ups west of Ireland, the vast momentum of Europ

ean research that followed has contributed to clarify the environmental setting of this important deep carbonate factory. Once again, ocean exploration meets rock science. In the meantime however, new techniques have emerged to boost our insight in both modern and ancient carbonate systems. In modern ocean research, the power and resolution of acoustic and 3D seismic imaging from the seabed to the deep subsurface, combined with advances in physical and chemical oceanography and state-of-the-art ocean drilling, shed a new light on the setting of these deep-water carbonate factories. At the analytical level, isotopic and molecular techniques, rock imaging beyond the micrometer scale and ex-situ experimentation in continuous high-pressure bioreactors have dramatically developed our capacity to characterize the physical and chemical controls, processes, products and fate of the carbonate factory - modern carbonate research has definitively moved into multi-disciplinarity. No single proxy allows uniquely reconstructing paleo-bathymetry, -density, -temperature or -salinity, paleo-productivity or paleo-circulation. Combining multi-scale imaging with fingerprinting through multiple proxies and tracers provides the keys, and dedicated protocols will control their portability into deep time.

There is however one fundamental difference of the present move, compared to the comparative studies initiated in the nineteenth century. Today's convergence of visions "from the ocean" and "from the rock" is a balanced, two-way track.

- The new insights in modern deep-water carbonate systems, and the perspective to even move to large-scale experimentation in realworld oceanic field laboratories, offer to carbonate scientists new views on old mounds. Mounds are giant biogeochemical reactors, turning energy into geology. In terms of energy sourcing and processing, the carbonate world parts into two worlds: a surface world, tightly coupled to light as energy source, and a deep world, where the fluxes of nutrients are to a significant extent controlled by the dynamics at the boundary between the upper water masses and the lower, thermohaline circulation cell. This subdivision largely meets James's (1997) classification into a photozoan and a heterozoan world, in terms of key players, however revised in depth, the heterozoan carbonate factory extending to much deeper reaches than previously ever considered.

- The new insights in the coupling between deep-water mounds and water mass boundaries can offer to ocean scientists new views on old oceans, in particular on the stratification and compartmentalization of past oceans into upper masses, driven by atmospheric circulation, and deeper water masses, driven by thermohaline circulation.

\section{Ocean dynamics}

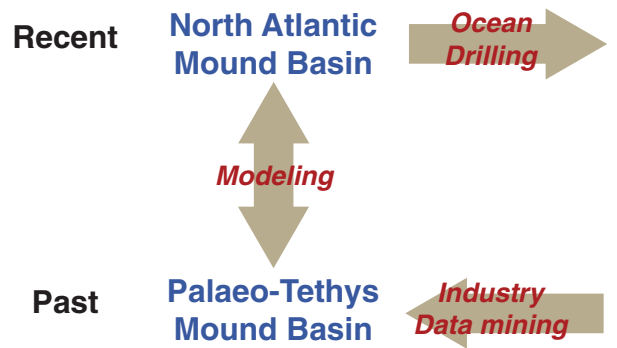

Mound controls

Atlantic Mound Lab

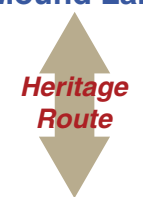

Ancient Mounds
Fig. 14. Mound research will progress through comparative studies between mound basins and provinces in the modern ocean - true experimental laboratories offering full access to environmental controls - and mound basins in targeted time slices in deep time. A prime step ahead is the comparison between the deep mound factories of the North Atlantic, increasingly documented by ocean coring and drilling, and those of the Paleo-Tethys, commonly of industrial interest. Strategic mound routes will provide the forum for the confrontation of ideas and concepts between academic and industrial communities, between the science of the ocean and the science of the rocks. Modeling of the dynamics of past oceans, constrained by the mound record and advanced oceanographic research, may shed light on past scenarios of thermohaline circulation, and enhance opportunities to assess the fate of the present global circulation. 
Reversely, this exercise can spur new views on the present ocean: the identification of the North Atlantic Mound Basin as an individualized entity can further foster an integrated, cross-Atlantic and targeted research program on both American and Euro/African margins, with well-coordinated drilling initiatives.

The exchange of ideas within such an expanding, multi-disciplinary community and in the developing project architecture will take benefit of an accessible continental field laboratory, offering to mixed parties of ocean and rock scientists a diversity of inspiring case studies (Fig. 14). The mound route that develops in Morocco may serve this objective, as a forum for discussions and as a reference site for academic and industrial training and research.

The completion of the scientific documentation of this route, which should include scientific drilling and high-resolution study meeting current standards of ocean drilling research, will leverage local academic development and capacity building. A visitor's center in the Tafilalt, covering both the natural and cultural richness of this fascinating region, would fill a major gap. The renaissance of the $\mathrm{Al}$ Andalus heritage in South Spain, which has enjoyed in recent decades active support from the EU, has generated high quality outreach material about the Almorávides and Almohades world, readily available for add-on valorization in the Tafilalt. The "Route Royale des Monts Carbonatés du Maroc" will serve science and society, equally.

\section{Acknowledgments}

Reflections in this paper were to some extent formulated in a keynote of the lead author at the 5th International Symposium on DeepSea Corals in Amsterdam, The Netherlands, June 2012. He gratefully acknowledges the organizers for this opportunity. The research on modern carbonate mounds, which triggered and fuelled these reflections, is however a vast collective effort.

The concept of a Heritage Route of carbonate mounds in Morocco has rooted in the October 2011 workshop and field seminar in Rabat, organized and courteously hosted by the Faculty of Sciences of the Mohamed V Rabat-Agdal University. This workshop and the field seminar in the High Atlas and eastern Anti-Atlas was co-organized by the Cadi Ayad University of Marrakech, the Ibn Battuta Centre, the International University of Rabat and the Office National des Hydrocarbures et des Mines (ONHYM). Support was provided from the Research Network Programme (RNP) of the European Science Foundation (ESF) "COCARDE-ERN" (2011-2016, www.esf.org/cocarde) and the International Coordination Action "COCARDE-ICA" under the auspices of IOC-UNESCO and supported by the Research Foundation Flanders FWO (2009-2015, www.cocarde.eu). The research reported has largely benefited from the EU projects ENAM II, CORSAIRES, ECOMOUND, GEOMOUND, ACES, EURODOM, OMARC, HERMES and HERMIONE, the ESF EUROCORES projects MoundForce and MVSeis (EuroMargins), MiCROSYSTEMS (EuroDiversity) and Carbonate (EuroMARC), the Integrated Ocean Drilling Program (IODP Exp. 307), the ESF RNP Magellan and various national projects. Cold-water coral mound research is much indebted to the IOC-UNESCO Training Through Research (TTR) program, from the TTR7 cruise onwards (1997). The authors wish hereby to pay tribute to Prof. Mikhail Konstantinovich Ivanov (1945-2012), inspired and indefatigable leader of the TTR program. The authors further wish to acknowledge the support of the reviewers, who significantly contributed to improve this manuscript in style and contents.

Anneleen Foubert was funded through a grant of the Research Foundation - Flanders (FWO).

Bodil W. Lauridsen was funded by a post doctoral research grant from the Carlsberg Foundation.

A.C. Da Silva acknowledges the UNESCO projects IGCP-580 and 596.

\section{References}

Adams, E.W., Grotzinger, J.P. Watters, W A Schröder S, McCormick, D. S, Al-Siyabi, H.A 2005. Digital characterization of thrombolite-stromatolite reef distribution in a carbonate ramp system (terminal Proterozoic, Nama Group, Namibia). AAPG Bulletin 89 (10), 1293-1318.

Ahr. W.M. 1989. Sedimentary and tectonic controls on the development of an early Mississippian carbonate ramp, Sacramento Mountains area, New Mexico. In: Crevello, P., Wilson, J.L., Sarg, J.F.R., Read, J.F. (Eds.), Controls on Carbonate Platforms and Basin Development. SEPM Special Publication, 44, pp. 203-212 (Tulsa, Oklahoma).

Ait Addi, A., 1998. Nouvelles données sédimentologiques et géodynamiques sur les faciès de l'Aalénien-Bajocien inférieur du Haut Atlas marocain (Nord d'Errachidia). Comptes Rendus de l'Académie des Sciences - Series IIA - Earth and Planetary Science 326, 193-200.

Aitken, J.D., 1967. Classification and environmental significance of cryptalgal limestones and dolomites, with illustrations from the Cambrian and Ordovician of southwestern Alberta. Journal of Sedimentary Petrology 37, 1163-1178.

Aitken, S.A., Collom, C.J., Henderson, C.J., Johnson, P.A., 2002. Stratigraphy, paleoecology, and origin of Lower Devonian (Emsian) carbonate mud buildups, Hamar Laghdad, eastern Anti-Atlas, Morocco, Africa. Bulletin of Canadian Petroleum Geology 50, 217-243.

Álvarez-Pérez, G., Busquets, P., De Mol, B., Sandoval, N.G., Canals, M., Casamor, J.L., 2005 Deep-water coral occurrences in the Strait of Gibraltar. In: Freiwald, A., Roberts, J.M. (Eds.), Cold-water Corals and Ecosystems. Springer Verlag, Berlin, Heidelberg, pp. 207-221.

Álvaro, J.J., Aretz, M., Boulvain, F., Munnecke, A., Vachard, D., Vennin, E. (Eds.), 2007. Palaeozoic Reefs and Bioaccumulations: Climatic and Evolutionary Controls. Geological Society Special Publications, 275, p. 291.

Barbieri, R., Ori, G.G., Cavalazzi, B., 2004. A Silurian cold-seep ecosystem from the Middle Atlas, Morocco. Palaios 19, 522-542.

Beauchamp, B., Baud, A., 2002. Growth and demise of Permian biogenic chert along northwest Pangea: evidence for end-Permian collapse of thermohaline circulation. Palaeogeography, Palaeoclimatology, Palaeoecology 184, 37-63.

Beauchamp, B., Desrochers, A., 1997. Permian warm- to very cold-water carbonates and cherts in northwest Pangea. In: James, N.P., Clarke, J. (Eds.), Cool Water Carbonates. SEPM Special Publication, 56, pp. 327-347.

Belka, Z, 1998. Early Devonian Kess-Kess carbonate mud mounds of the eastern AntiAtlas (Morocco), and their relation to submarine hydrothermal venting. Journal of Sedimentary Research 68, 369-377.

Belka, Z., Berkowski, B., 2005. Discovery of thermophilic corals in an ancient hydrothermal vent community, Devonian, Morocco. Acta Geologica Polonica 55 (1), 1-7.

Bengtson, S., Zhao, Y., 1992. Predatorial borings in Late Precambrian mineralized exoskeletons. Science 257, 367-369.

Benson, R.H., Rakic-El Bied, K., Bonaduce, G., 1991. An important current reversal (influx) in the Rifian Corridor (Morocco) at the Tortonian-Messinian boundary: the end of the Tethys ocean. Paleoceanography 6 (1), 164-192.

Beuck, L., Freiwald, A., 2005. Bioerosion patterns in a deep-water Lophelia pertusa (Scleractinia) thicket (Propeller Mound, northern Porcupine Seabight). In: Freiwald, A., Roberts, J.M. (Eds.), Cold-water Corals and Ecosystems. Springer Verlag, Berlin, Heidelberg, pp. 915-936.

Beuck, L. Vertino, A. Stepina, E., Karolczak, M. Pfannkuche, O, 2007. Skeletal response of Lophelia pertusa (Scleractinia) to bioeroding sponge infestation visualised with micro-computed tomography. Facies 53, 157-176.

Bjerager, M., Surlyk, F., 2007. Danian cool-water bryozoan mounds at Stevns Klint, Denmark-a new class of non-cemented skeletal mounds. Journal of Sedimentary Research 77, 634-660.

Bonnin, J., Van Haren, H., Hosegood, P., Brummer, G.J.A., 2006. Burst resuspension of seabed material at the foot of the continental slope in the Rockall Channel. Marine Geology $226,167-184$

Bosence, D.W.. Bridges, P.H. 1995. A review of the origin and evolution of carbonate mud-mounds. In: Monty, C.LV, Bosence, D.W. Bridges, P.H, Pratt, B.R. (Eds.), Carbonate Mud-mounds. Their Origin and Evolution. International Association of Sedimentologists Special Publication, 23, pp. 3-9.

Boulvain, F., 2007. Frasnian carbonate mounds from Belgium: sedimentology and palaeoceanography. In: Álvaro, JJ, Aretz, M., Boulvain, F, Munnecke, A., Vachard, D. Vennin, E. (Eds.), Palaeozoic Reefs and Bioaccumulations: Climatic and Evolutionary Controls. Geological Society Special Publications, 275, pp. 125-142.

Boyle, R.A., Lenton, T.M., Williams, H.T.P., 2007. Neoproterozoic 'snowball earth' glaciations and the evolution of altruism. Geobiology 5, 337.

Brachert, T.C., Buggish, W., Flügel, E., Hüssner, H.M., Joachimski, M.M., Tourner, F., Walliser, O.H., 1992. Controls of mud mound formation: the Early Devonian KessKess carbonates of the Hamar Laghdad, Antiatlas, Morocco. Geologische Rundschau $81,15-44$.

Brown, J., Colling, A., Park, D., Philips, J., Rothery, D., Wright, J., 1989a. The Open University. Ocean CirculationPergamon Press, Oxford 238.

Brown, J., Colling, A., Park, D., Philips, J., Rothery, D., Wright, J., 1989b. The Open University. Ocean Chemistry and Deep-sea SedimentsPergamon Press, Oxford 134.

Brunsden, D. (Ed.), 2003. The Official Guide to the Jurassic Coast. Dorset and East Devon's World Heritage Coast. Coastal Publishing, p. 64.

Cairns, S.D., 2007. Deep-water corals: an overview with special reference to diversity and distribution of deep-water scleractinian corals. Bulletin of Marine Science 81 (3), 311-322.

Cairns, S.D., Macintyre, I.G., 1992. Phylogenetic implications of calcium carbonate mineralogy in the Stylasteridae (Cnidaria: Hydrozoa). Palaios 7, 96-107.

Came, R.E., Eiler, J.M., Veizer, J., Azmy, K., Brand, U., Weidman, C.R., 2007. Coupling of surface temperature and atmospheric $\mathrm{CO}_{2}$ concentrations during the Paleozoic era. Nature 449, 198-201 
Camoin, G.F., Seard, C., Deschamps, P., Webster, J.M., Abbey, E., Braga, J.C., Iryu, Y., Durand, N., Bard, E., Hamelin, B., Yokohama, Y., Thomas, A.L., Henderson, G.M., Dussouillez, P., 2012. Reef response to sea-level and environmental changes during the last deglaciation: Integrated Ocean Drilling Program Expedition 310, Tahiti Sea Level. Geology 40 (7), 643-646.

Cavalazzi, B., Barbieri, R., Ori, G.G., 2007. Chemosynthetic microbialites in the Devonian Kess Kess mounds (Anti-Atlas, Morocco). Sedimentary Geology 200, 73-88.

Chafiki, D., Canérot, J., Souhel, A., El Hariri, Kh., Taj Eddine, K., 2004. The Sinemurian carbonate mud-mounds from central High Atlas (Morocco): stratigraphy, geometry, sedimentology and geodynamic patterns. Journal of African Earth Sciences 39, 337-346.

Cherns, L., Wright, V.P., 2000. Missing molluscs as evidence of large-scale, early skeletal aragonite dissolution in a Silurian sea. Geology 28 (9), 791-794.

Colman, J.G., Gordon, D.M., Lane, A.P., Forde, M.J., Fitzpatrick, J.J., 2005. Carbonate mounds off Mauritania, Northwest Africa: status of deep-water corals and implications for management of fishing and oil exploration activities. In: Freiwald, A., Roberts, J.M. (Eds.), Cold-water Corals and Ecosystems. Springer Verlag, Berlin, Heidelberg, pp. 417-441.

Colpaert, A., 2007. Geophysical Characterisation of Carboniferous-Permian Carbonate Platforms in the Barents Sea Based on 3D-seismic Data Analysis and Rock Physics Modelling. (PhD Thesis) University of Tromsoe, Norway 145.

Colpaert, A., Pickard, N., Mienert, J., Henriksen, L.B., Rafaelsen, B., Andreassen, K., 2007. 3D seismic analysis of an Upper Palaeozoic carbonate succession of the Eastern Finnmark Platform area, Norwegian Barents Sea. Sedimentary Geology 197 (1), 79-98.

Comas, M.C., Pinheiro, L., Ivanov, M., TTR-17 Leg 1 Scientific Party, 2009. Deep-water coral mounds in the Alboran Sea: the Melilla mound field revisited. In: Comas, M.C., Suzyumov, A. (Eds.), Geo-Marine Research on the Mediterranean and European-Atlantic Margins. IOC Workshop Report, 220, pp. 8-9.

Conway, K.W., Krautter, M., Vaughn Barrie, J., Whitney, F., Thomson, R.E., Reiswig, H. Lehnert, H., Mungov, G., Bertram, M., 2005. Sponge reefs in the Queen Charlotte Basin, Canada: controls on distribution, growth and development. In: Freiwald, A., Roberts, J.M. (Eds.), Cold-water Corals and Ecosystems. Springer Verlag, Berlin, Heidelberg, pp. 605-621.

Copper, P., 2001. Evolution, radiations, and extinctions in Proterozoic to Mid-Paleozoic reefs. In: Stanley Jr., G.D. (Ed.), The History and Sedimentology of Ancient Reef Systems. Kluwer Academic/Plenum Publishers, pp. 89-119.

Correa, T.B.S., Eberli, G.P., Grasmueck, M., Reed, J.K., Correa, A.M.S., 2012. Genesis and morphology of cold-water coral ridges in a unidirectional current regime. Marine Geology 326-328, 14-27.

Damholt, T., Surlyk, F., 2012. Nomination of Stevns Klint for Inclusion in the World Heritage List. Østsjællands Museum, Denmark 160.

Darwin, E., 1791. The botanic garden; a poem, in two parts. Part I - containing the economy of vegetation, 214 pp. +126 pp. Additional Notes. Part II - the Love of the Plants. J. Johnson, London, p. 184.

Darwin, C., 1842. The Structure and Distribution of Coral Reefs. Smith, Elder and Co., 65 Cornhill, London 214

Darwin, C., 1878. Les récifs de corail. Leur structure et leur distribution. (Translation by M.L. Cosserat) Libraire Germer Baillière et Cie, Paris 347.

Dawkins, R., 1976. The Selfish Gene. Oxford University Press, p. 352.

de Dorlodot, H., 1909. Les faunes du Dinantien et leur signification stratigraphique. Bulletin de la Société Belge de Géologie 23, 153-174.

De Mol, B., Van Rensbergen, P., Pillen, S., Van Herreweghe, K., Van Rooij, D. McDonnell, A., Huvenne, V., Ivanov, M., Swennen, R., Henriet, J.P., 2002. Large deep-water coral banks in the Porcupine Basin, southwest of Ireland. Marine Geology 188, 193-231.

De Mol, L., Van Rooij, D., Pirlet, H., Greinert, J., Frank, N., Quemmerais, F., Henriet, J.P., 2011. Cold-water coral habitats in the Penmarc'h and Guilvinec canyons (Bay of Biscay): deep-water versus shallow-water settings. Marine Geology 282, 40-52.

Decho, A.W., Visscher, P.T., Reid, R.P., 2005. Production and cycling of natural microbial exopolymers (EPS) within a marine stromatolite. Palaeogeography, Palaeoclimatology, Palaeoecology 219, 71-86.

Della Porta, G., 2003. Depositional Anatomy of a Carboniferous High-rising Carbonate Platform (Cantabrian Mountains, NW Spain). (PhD Thesis) Vrije Universiteit, Amsterdam 250.

Depreiter, D., 2009. Sources, Modes and Effects of Seabed Fluid Flow. (PhD Thesis) Universiteit Gent, Gent 207.

Devuyst, F.X., Lees, A., 2001. The initiation of Waulsortian buildups in Western Ireland. Sedimentology 48, 1121-1148.

Dewalque, G., 1868. Prodrome d'une description géologique de la Belgique. Imp. Carmanne, Liège 442

Dorschel, B., Hebbeln, D., Rüggeberg, A., Dullo, W.-C., Freiwald, A., 2005. Growth and erosion of a cold-water coral covered carbonate mound in the Northeast Atlantic during the Late Pleistocene and Holocene. Earth and Planetary Science Letters 233, 33-44.

Dorschel, B., Wheeler, A.J., Monteys, X., Verbruggen, K., 2010. Atlas of the Deep-water Seabed, Ireland. Springer-Verlag, p. 164.

Dullo, W.-C., Flögel, S., Rüggeberg, A., 2008. Cold-water coral growth in relation to the hydrography of the Celtic and Nordic European continental margin. Marine Ecology Progress Series 371, 165-176.

Dupont, E., 1881. Les îles coralliennes de Roly et de Philippeville. Bulletin de l'Academie Royale des Sciences, des Lettres et des Beaux-Arts de Belgique 3e (II), 89-160.

Dupraz, C., Reid, R.P., Braissant, O., Decho, A.W., Norman, R.S., Visscher, P.T., 2009. Processes of carbonate precipitation in modern microbial mats. Earth-Science Reviews 96 , $141-152$.
Eiler, J.M., 2011. Paleoclimate reconstruction using carbonate clumped isotope thermometry. Quaternary Science Reviews 30, 3575-3588.

Eisele, M., Frank, N., Wienberg, C., Hebbeln, D., Correa, M.L., Douville, E., Freiwald, A., 2011. Productivity controlled cold-water coral growth periods during the last glacial off Mauritania. Marine Geology 280, 143-149.

Elliott, S., Hsu, H.H., O'Hearn, T., Sylvester, I.F., Vercesi, R., 1998. The giant Karachaganak field, unlocking its potential. Oilfield Review 1998, 16-25 (Autumn).

Fagerstrom, J.A., 1991. Reef-building guilds and a checklist for determining guild membership. Coral Reefs 10, 47-52.

Ferdelman, T.G., Kano, A., Williams, T., the IODP Expedition Scientists, 2006. IODP Expedition 307 Drills Cold-water Coral Mound Along the Irish Continental Margin. Scientific Drilling 2. http://dx.doi.org/10.2204/iodp.sd.2.02.2006 (March).

Flügel, E., 2004. Microfacies of carbonate rocks. Analysis, Interpretation and ApplicationSpringer-Verlag 976.

Flügel, E., Kiessling, W., 2002. A new look at ancient reefs. In: Kiessling, W., Flügel, E., Golonka, J. (Eds.), Phanerozoic Reef Patterns. SEPM Special Publication, 72, pp. 3-10.

Fosså, J.H., Lindberg, B., Christensen, O., Lundalv, T., Svellingen, I., Mortensen, P., Alvsvaag, J., 2005. Mapping of Lophelia reefs in Norway: experiences and survey methods. In: Freiwald, A., Roberts, J.M. (Eds.), Cold-water Corals and Ecosystems. Springer Verlag, Berlin, Heidelberg, pp. 359-391.

Foubert, A., Henriet, J.-P., 2009. Nature and significance of the recent carbonate mound record. Lecture Notes in Earth Sciences, 126. Springer-Verlag, Berlin, Heidelberg, p. 298

Foubert, A., Depreiter, D., Beck, T., Maignien, L., Pannemans, B., Frank, N., Blamart, D., Henriet, J.P., 2008. Carbonate mounds in a mud volcano province off northwest Morocco: key to processes and controls. Marine Geology 248, 74-96.

Foubert, A., Huvenne, V.A.I., Wheeler, A., Kozachenko, M., Opderbecke, J., Henriet, J.P., 2011. The Moira Mounds, small cold-water coral mounds in the Porcupine Seabight, NE Atlantic: part B-evaluating the impact of sediment dynamics through high-resolution ROV-borne bathymetric mapping. Marine Geology 282, 65-78.

Frakes, L.A., Francis, J.E., Syktus, J.I., 1992. Climate Modes of the Phanerozoic: the History of the Earth's Climate Over the Past 600 Million Years. Cambridge University Press, Cambridge 274

Frank, T.D., Titschack, J., Thierens, M., 2010. Aragonite loss in a cold-water coral mound: mechanisms and implications. Sedimentology 58, 670-690.

Frank, N., Freiwald, A., López Correa, M., Wienberg, C., Eisele, M., Hebbeln, D., Van Rooij, D.V., Henriet, J.-P., Colin, C., van Weering, T., de Haas, H., BuhlMortensen, P., Roberts, J.M., De Mol, B.D., Douville, E., Blamart, D., Hatte, C., 2011. Northeastern Atlantic cold-water coral reefs and climate. Geology 39 (8), 743-746.

Freiwald, A., 1998. Geobiology of Lophelia pertusa (Scleractinia) in the North Atlantic. Habilitation ThesisBremen University 116.

Freiwald, A., Roberts, J.M. (Eds.), 2005. Cold-Water Corals and Ecosystems. Erlangen Earth Conference Series, Springer-Verlag Berlin Heidelberg, p. 1243.

Freiwald, A., Fosså, J.H., Grehan, A., Koslow, T., Roberts, J.M., 2004. Cold-water Coral Reefs. UNEP-WCMC, Cambridge, UK 84.

Golonka, J., 2002. Plate-tectonic maps of the Phanerozoic. In: Kiessling, W., Flügel, E., Golonka, J. (Eds.), Phanerozoic Reef Patterns. SEPM Special Publication, 72, pp. 21-75.

Grotzinger, J.P., 1989. Facies and evolution of Precambrian carbonate depositional systems: emergence of the modern platform archetype. In: Crevello, P.D., Wilson, J.L., Sarg, J.F., Read, J.F. (Eds.), Controls on Carbonate Platform and Basin Development. Society of Economic Paleontologists and Mineralogists Special Publication, 44, pp. 79-106.

Grotzinger, J.P., Watters, W.A., Knoll, A.H, 2000. Calcified metazoans in thrombolitestromatolite reefs of the terminal Proterozoic Nama Group, Namibia. Paleobiology 26, 334-359.

Grotzinger, J., Adams, E.W., Schröder, S., 2005. Microbial-metazoan reefs of the terminal Proterozoic Nama Group (c. 550-543 Ma), Namibia. Geological Magazine 142 (5), 499-517.

Guinotte, J.M., Orr, J., Cairns, S., Freiwald, A., Morgan, L., George, R., 2006. Will humaninduced changes in seawater chemistry alter the distribution of deep-sea scleractinian corals? Frontiers in the Ecology and the Environment 4 (3), 141-146.

Halverson, G.P., Hoffman, P.F., Schrag, P., Maloof, A.C., Rice, A.H.N., 2005. Toward a Neoproterozoic composite carbon-isotope record. Geological Society of America Bulletin $117,1181-1207$.

Hamoumi, N., 1999. Upper Ordovician glaciation spreading and its sedimentary record in Moroccan North Gondwana margin. Acta Universitatis Carolinae. Geologica 43 (1/2), 111-114.

Haq, B.U., Shutter, S.R., 2008. A chronology of Paleozoic sea-level changes. Science 322 64-68.

Haq, B.U., Hardenbol, J., Vail, P.R., 1987. Chronology of fluctuating sea level since the Triassic. Science 235, 1156-1167.

Hardenbol, J., Thierry, J., Farley, M.B., Jacquin, T., de Graciansky, P.C., Vail, P., 1998. Mesozoic and Cenozoic sequence chronostratigraphic framework of European basins. In: de Graciansky, P.C., Hardenbol, J., Jacquin, T., Vail, P.R. (Eds.), Mesozoic and Cenozoic Sequence Stratigraphy of European Basins. SEPM Special Publication, 60, pp. 3-13.

Harland, W.B., Rudwick, M.J.S., 1964. The great infra-Cambrian glaciation. Scientific American 211, 28-36.

Henriet, J.P., De Mol, B., Pillen, S., Vanneste, M., Van Rooij, D., Versteeg, W., Croker, P.F., Shannon, P.M., Unnithan, V., Bouriak, S., Chachkine, P., 1998. Gas hydrate crystals may help build reefs. Nature 391, 648-649.

Henriet, J.P., Guidard, S., the ODP "Proposal 573" Team, 2002. Carbonate mounds as a possible example for microbial activity in geological processes. In: Wefer, G., 
Billett, D., Hebbeln, D., Jørgensen, B.B., Schlüter, M., van Weering, T. (Eds.), Ocean Margin Systems. Springer Verlag, Berlin, Heidelberg, New York, pp. 437-455.

Henriet, J.P., Spezzaferri, S., Samankassou, E., Foubert, A., Van Rooij, D., Rüggeberg, A., 2011. Carbonate mounds in shallow and deep time. Marine Geology 282, 1-4.

Hernández-Molina, F., Serra, N., Stow, D., Llave, E., Ercilla, G., Van Rooij, D., 2011. Alongslope oceanographic processes and sedimentary products around the Iberian margin. Geo-Marine Letters 31, 315-341.

Hoffman, P.F., Schrag, D.P., 2000. Snowball Earth. Scientific American 282, 68-75.

Hoffman, P.F., Kaufman, A.J., Halverson, G.P., Schrag, D.P., 1998. A Neoproterozoic snowball Earth. Science 281, 1342-1346.

Hovland, M., Croker, P.F., Martin, M., 1994. Fault-associated seabed mounds (carbonate knolls?) off western Ireland and north-west Australia. Marine and Petroleum Geology 11 (2), 232-246.

Huvenne, V., De Mol, B., Henriet, J.-P., 2003. A 3D seismic study of the morphology and spatial distribution of buried coral banks in the Porcupine Basin, SW of Ireland. Marine Geology 198, 5-25

Huvenne, V.A.I., Bailey, W.R., Shannon, P.M., Naeth, J., di Primio, R., Henriet, J.-P., Horsfield, B., de Haas, H., Wheeler, A., Olu-Le Roy, K., 2007. The Magellan mound province in the Porcupine Basin. International Journal of Earth Sciences 96, 85-101.

Huvenne, V.A.I., Masson, D.G., Wheeler, A.J., 2009. Sediment dynamics of a sandy contourite: the sedimentary context of the Darwin cold-water coral mounds, Northern Rockall Trough. International Journal of Earth Sciences 98, 865-884.

Huvenne, V.A.I., Tyler, P.A., Masson, D.G., Fisher, E.H., Hauton, C., Hühnerbach, V., Le Bas, T.P., Wolff, G.A., 2011. A Picture on the wall: innovative mapping reveals coldwater coral refuge in submarine canyon. PLoS ONE 6, e28755.

Huvenne, V.A.I., Pattenden, A.D.C., Masson, D., Tyler, P., 2012. Habitat heterogeneity in deep-sea canyons offshore Portugal. In: Harris, P.T. Baker, E.K. (Eds.), Seafloor Geomorphology as Benthic Habitat. GeoHAB Atlas of Seafloor Geomorphic Features and Benthic Habitats. Elsevier, London, pp. 691-701.

Immenhauser, A., 2009. Estimating palaeo-water depth from the physical rock record. Earth-Science Reviews 96, 107-139.

James, N.P., 1997. The cool-water carbonate depositional realm. In: James, N.P., Clarke, J.A.D. (Eds.), Cool-water Carbonates. SEPM Special Publication, 56. SEPM, Tulsa, Oklahoma, U.S.A., pp. 1-20.

James, N.P., 2001. Foreword. In: Stanley Jr., G.D. (Ed.), The History and Sedimentology of Ancient Reef Systems. Kluwer Academic/Plenum Publishers, pp. vii-viii.

James, N.P., Bone, Y., Kyser, T.K., 2005. Where has all the aragonite gone? Mineralogy of Holocene neritic cool-water carbonates, southern Australia. Journal of Sedimentary Research 75 (3), 454-463.

James, N.P., Frank, T.D., Fielding, C.R., 2009. Carbonate sedimentation in a Permian highlatitude, subpolar depositional realm: Queensland, Australia. Journal of Sedimentary Research 79, 125-143.

Kalkowsky, E., 1908. Oolith und Stromatolith im norddeutschen Buntsandstein. Zeitschrift der Deutschen Geologischen Gesellschaft 60, 68-125.

Kano, A., Ferdelman, T.G., Williams, T., Henriet, J.-P., Ishikawa, T., Kawagoe, N., Takashima, C., Kakizaki, Y., Abe, K., Sakai, S., Browning, E.L., Li, X., the IODP Expedition 307 Scientists, 2007. Age constraints on the origin and growth history of a deep-water coral mound in the northeast Atlantic drilled during Integrated Ocean Drilling Program Expedition 307. Geology 35 (11), 1051-1054.

Kiessling, W., 2001. Phanerozoic reef trends based on the paleoreef database. In: Stanley Jr., G.D. (Ed.), The History and Sedimentology of Ancient Reef Systems. Topics in Geobiology, 17. Kluwer Academic/Plenum Publishers, pp. 41-88.

Kiessling, W., 2009. Geologic and biologic controls on the evolution of reefs. Annual Review of Ecology, Evolution, and Systematics 40, 173-192.

Kiessling, W., Flügel, E., Golonka, J. (Eds.), 2002. Phanerozoic Reef Patterns. SEPM Special Publication 72. Society for Sedimentary Geology, Tulsa, Oklahoma, USA, p. 775.

Knoll, A.H., 2003. Life on a young planet. The First Three Billion Years of Evolution on EarthPrinceton University Press 275.

Krause, F.F., Scotese, C.R., Nieto, C., Sayegh, S.G., Hopkins, J.C., Meyer, R.O., 2004. Paleozoic stromatactis and zebra carbonate mud-mounds: global abundance and paleogeographic distribution. Geology 32 (3), 181-184.

Lauridsen, B.W., Bjerager, M., 2014. Danian cold-water corals from the Baunekule facies, Faxe Formation, Denmark: a rare taphonomic window of a coral mound flank habitat. Lethaia. http://dx.doi.org/10.1111/let.12060.

Lauridsen, B.W., Bjerager, M., Surlyk, F., 2012. The middle Danian Faxe Formation - new lithostratigraphic unit and a rare taphonomic window into the Danian of Denmark. Bulletin of the Geological Society of Denmark 60, 47-60.

Le Danois, E., 1948. Les profondeurs de la mer. Trente ans de recherches sur la faune sousmarine au large des côtes de France. Payot, Paris 303.

Lees, A., Buller, A.T., 1972. Modern temperate-water and warm-water shelf carbonate sediments contrasted. Marine Geology 13, M67-M73.

Lees, A., Miller, J., 1995. Waulsortian banks. In: Monty, C.L.V., Bosence, D.W.J., Bridges, P.H., Pratt, B.R. (Eds.), Carbonate Mud-mounds. Their Origin and Evolution. International Association of Sedimentologists Special Publication, 23, pp. 191-271.

Lenton, T., Watson, A., 2011. Revolutions That Made the Earth. Oxford University Press, p. 423.

Logan, B.W., Hoffman, P., Gebelein, C.D., 1974. Algal mats, cryptalgal fabrics, and structures, Hamelin Pool, western Australia. In: Logan, B.W., Read, J.F., Hagan, G.M., Hoffman, P., Brown, R.G., Woods, P.J., Gebelein, C.D. (Eds.), Evolution and Diagenesis of Quaternary Carbonate Sequences, Shark Bay, Western Australia. American Association of Petroleum Geologists Memoir, 22, pp. 140-191.

Love, G.D., Grosjean, E., Stalvies, C., Fike, D.A., Grotzinger, J.P., Bradley, A.S., Kelly, A.E., Bhatia, M., Meredith, W., Snape, C.E., Bowring, S.A., Condon, D.J., Summons, R.E., 2009. Fossil steroids record the appearance of Demospongiae during the Cryogenian period. Nature $457,718-721$.
Maignien, L., Depreiter, D., Foubert, A., Reveillaud, J., De Mol, L., Boeckx, P., Blamart, D. Henriet, J.P., Boon, N., 2010. Anaerobic oxidation of methane in a cold-water coral carbonate mound from the Gulf of Cadiz. International Journal of Earth Sciences 99 (3). $1-10$

Marshall, J., Plumb, R.A., 2008. Atmosphere, ocean and climate dynamics: an introductory text. Academic Press, p. 344

Masson, D.G., Bett, B.J., Billett, D.S.M., Jacobs, C.L., Wheeler, A.J., Wynn, R.B., 2003. The origin of deep-water, coral-topped mounds in the northern Rockall Trough, Northeast Atlantic. Marine Geology 194, 159-180.

Mazzini, A., Akhmetzhanov, A., Monteys, X., Ivanov, M., 2011. The Porcupine Bank Canyon coral mounds: oceanographic and topographic steering of deep-water carbonate mound development and associated phosphatic deposition. Geo-Marine Letters 32 205-225

Mc Ghee Jr., G.R., Orth, C.J., Quintana, L.R., Gilmore, J.S., Olsen, E.J., 1986. Geochemical analyses of the Late Devonian "Kellwasser Event" stratigraphic horizon at Steinbruch Schmidt (F.R.G.). Global Bio-Events. Lecture Notes in Earth Sciences 8, 219-224.

Meincke, J., 2002. Climate dynamics of the North Atlantic and NW-Europe: an observationbased overview. In: Wefer, G., Berger, W. Behre, K.-E, Jansen, E. (Eds.), Climate Deveopment and History of the North Atlantic Realm. Springer-Verlag. Berlin Heidelberg pp. 25-40.

Mienis, F., 2007. Environmental constraints on cold-water coral growth and carbonate mound formation. (PhD Thesis) Amsterdam Free University 209.

Mienis, F., de Stigter, H.C., White, M., Duineveld, G., de Haas, H., van Weering, T.C.E., 2007. Hydrodynamic controls on cold-water coral growth and carbonate-mound development at the SW and SE Rockall Trough Margin, NE Atlantic Ocean. Deep-Sea Research I 54, 1655-1674.

Mienis, F., van Weering, T., de Haas, H., de Stigter, H., Huvenne, V., Wheeler, A., 2006. Carbonate mound development at the SW Rockall Trough margin based on high resolution TOBI and seismic recording. Marine Geology 233, 1-19.

Monty, C.L.V., 1995. The rise and nature of carbonate mud-mounds: an introductory actualistic approach. In: Monty, C.L.V., Bosence, D.W.J., Bridges, P.H., Pratt, B.R. (Eds.), Carbonate Mud-mounds. Their Origin and Evolution. International Association of Sedimentologists Special Publication, 23, pp. 11-48.

Monty, C.L.V., Bernet-Rollande, M.C., Maurin, A.F., 1982. Re-interpretation of the Frasnian classical "reefs" of the southern Ardennes, Belgium. Extended abstract. Annales de la Société Géologique de Belgique 105, 339-341.

Mounji, D., Bourque, P.-A., Savard, M.M., 1998. Hydrothermal origin of Devonian conical mounds (Kess-Kess) of Hamar Lakhdad Ridge, Anti-Atlas, Morocco. Geology 26 (12), 1123-1126.

Mullins, H.T., Newton, C.R., Heath, K., Vanburen, H.M., 1981. Modern deep-water coral mounds north of Little Bahama Bank: criteria for recognition of deep-water coral bioherms in the rock record. Journal of Sedimentary Petrology 51 (3), 999-1013.

Muñoz, A., Cristobo, J., Rios, P., Druet, M., Polonio, V., Uchupi, E., Acosta, J., Group, A., 2012 Sediment drifts and cold-water coral reefs in the Patagonian upper and middle continental slope. Marine and Petroleum Geology 36, 70-82.

Naeth, J., di Primio, R., Horsfield, B., Schaefer, R.G., Krooss, B.M., 2007. On the relationship between hydrocarbon migration pathways and carbonate mound occurrence in the Porcupine Basin. International Journal of Earth Sciences 96, 199-200.

Neumann, A.C., Kofoed, J.W., Keller, G., 1977. Lithoherms in the Straits of Florida. Geology 5, 4-10.

Neuweiler, F., Gautret, P., Thiel, V., Lange, R., Michaelis, W., Reitner, J., 1999. Petrology of Lower Cretaceous carbonate mud mounds (Albian, N. Spain): insights into organomineralic deposits of the geological record. Sedimentology 46, 837-859.

Neuweiler, F., Mehdi, M., Wilsen, M., 2001. Facies of Liassic sponge mounds, central High Atlas, Morocco. Facies 44, 243-264.

Neuweiler, F., Turner, E.C., Burdige, D.J., 2009. Early Neoproterozoic origin of the metazoan clade recorded in carbonate rock texture. Geology 37 (5), 475-478.

New, A.L., 1987. Internal tidal currents in the Bay of Biscay. Advances in Underwater Technology, Ocean Science and Offshore Engineering. Modeling for Offshore Environment vol. 12. Society for Underwater Technology, Graham \& Trotman, Norwell, MA, USA, pp. 279-291.

Orr, J.C., Fabry, V.J., Aumont, O., Bopp, L., Doney, S.C., Feely, R.A., Gnanadesikan, A., Gruber N., Ishida, A., Joos, F., Key, R.M., Lindsay, K., Maier-Reimer, E., Matear, R., Monfray, P., Mouchet, A., Najjar, R.G., Plattner, G.-K., Rodgers, K.B., Sabine, C.L., Sarmiento, J.L, Schlitzer, R., Slater, R.D., Totterdell, I.J., Weirig, M.-F., Yamanaka, Y., Yool, A., 2005. Anthropogenic ocean acidification over the twenty-first century and its impact on calcifying organisms. Nature 437, 681-686.

Paull, C.K., Neumann, A.C., Ende, B.A.A., Ussler, W., Rodriguez, N.M., 2000. Lithoherms on the Florida-Hatteras slope. Marine Geology 166, 83-101.

Peckmann, J., Walliser, O.H., Riegel, W., Reitner, J., 1999. Signatures of hydrocarbon venting in a Middle Devonian carbonate mound (Hollard Mound) at the Hamar Laghdad (Antiatlas, Morocco). Facies 40, 281-296.

Peckmann, J., Little, C.T.S., Gill, F., Reitner, J., 2005. Worm tube fossils from the Hollard Mound hydrocarbon-seep deposit, Middle Devonian, Morocco: Palaeozoic seeprelated vestamentiferans? Palaeogeography, Palaeoclimatology, Palaeoecology 227, $242-257$.

Perrin, C., 2002. Tertiary: the emergence of modern reef ecosystems. In: Kiessling, W., Flügel, E., Golonka, J. (Eds.), Phanerozoic Reef Patterns. SEPM Special Publication, 72, pp. 587-621.

Perrin, C., Bosellini, F.R., 2012. Paleobiogeography of scleractinian reef corals: changing patterns during the Oligocene-Miocene climatic transition in the Mediterranean. Earth Science Reviews 111, 1-24.

Pirlet, H., Wehrmann, L.M., Brunner, B., Frank, N., Dewanckele, J., Van Rooij, D., Foubert, A., Swennen, R., Naudts, L., Boone, M., Cnudde, V., Henriet, J.-P., 2010. Diagenetic formation of gypsum and dolomite in a cold-water coral mound in the Porcupine Seabight, off Ireland. Sedimentology 57, 786-805. 
Pirlet, H., Wehrmann, L.M., Foubert, A., Brunner, B., Blamart, D., De Mol, L., Van Rooij, D., Dewanckele, J., Cnudde, V., Swennen, R., Duyck, Ph., Henriet, J.P., 2012. Unique authigenic mineral assemblages reveal different diagenetic histories in two neighbouring cold-water coral mounds on Pen Duick Escarpment, Gulf of Cadiz. Sedimentology 59, 578-604.

Pomar, L., Hallock, P., 2008. Carbonate factories: a conundrum in sedimentary geology. Earth-Science Reviews 87, 134-169.

Pratt, B.R., 1995. The origin, biota and evolution of deep-water mud-mounds. In: Monty, C.L.V., Bosence, D.W.J., Bridges, P.H., Pratt, B.R. (Eds.), Carbonate Mud-mounds. Their Origin and Evolution. International Association of Sedimentologists Special Publication, 23, pp. 49-123.

Read, J.F., 1998. Phanerozoic carbonate ramps from greenhouse, transitional and icehouse worlds: clues from field and modeling studies. In: Wright, V.P., Burchette, T.P. (Eds.), Carbonate Ramps. Geological Society of London, pp. 107-122.

Redfern, R., 2000. Origins. The Evolution of Continents, Oceans and LifeWeidenfeld and Nicolson, London 360.

Reed, J.K., 1980. Distribution and structure of deep-water Oculina varicosa coral reefs off central eastern Florida. Bulletin of Marine Science 30, 667-677.

Reveillaud, J., Freiwald, A., Van Rooij, D., Foubert, A., Le Guilloux, E., Altuna, A., Vanreusel, A., Olu-Le-Roy, K., Henriet, J.P., 2008. The distribution of scleractinian corals in the Bay of Biscay, NE Atlantic. Facies 54, 317-331.

Riding, R., 2005. Phanerozoic reefal microbial carbonate abundance: comparisons with metazoan diversity, mass extinction, events, and seawater saturation state. Revista Española de Micropaleontología 37 (1), 23-39.

Riding, R., 2011. The nature of stromatolites: 3,500 million years of history and a century of research. In: Reitner, J., et al. (Eds.), Advances in Stromatolite Geobiology. Lecture Notes in Earth Sciences, 131. Springer-Verlag, pp. 29-74.

Riding, R., Liang, L., 2005a. Geobiology of microbial carbonates: metazoan and seawater saturation state influences on secular trends during the Phanerozoic Palaeogeography, Palaeoclimatology, Palaeoecology 219, 101-115.

Riding, R., Liang, L., 2005b. Seawater chemistry control of marine limestone accumulation over the past 550 million years. Revista Española de Micropaleontología 37 (1), 1-11.

Roberts, J.M., Wheeler, A.J., Freiwald, A., 2006. Reefs of the deep: the biology and geology of cold-water coral ecosystem. Science 312, 543-547.

Roberts, J.M., Davies, A.J., Henry, L.A., Dodds, L.A., Duineveld, G.C.A., Lavaleye, M.S.S., Maier, C., van Soest, R.W.M., Bergman, M.J.N., Hühnerbach, V., Huvenne, V.A.I., Sinclair, D.J., Watmough, T., Longs, D., Green, S.L., van Haren, H., 2009. Mingulay reef complex: an interdisciplinary study of cold-water coral habitat, hydrography and biodiversity. Marine Ecology Progress Series 397, 139-151.

Roscher, M., Schneider, J.W., 2006. Permo-Carboniferous climate: early Pennsylvanian to late Permian climate development of central Europe in a regional and global context. In: Lucas, S.G., Cassinis, G., Schneider, J.W. (Eds.), Non-marine Permian Biostratigraphy and Biochronology. Geological Society Special Publications, 265, pp. 95-136.

Rüggeberg, A., Dullo, C., Dorschel, B., Hebbeln, D., 2007. Environmental changes and growth history of Propeller Mound, Porcupine Seabight: evidence from benthic foraminiferal assemblages. International Journal of Earth Sciences 96, 57-72.

Rüggeberg, A., Flögel, S., Dullo, W.-Chr., Hissmann, K., Freiwald, A., 2011. Water mass characteristics and sill dynamics in a subpolar cold-water coral reef seeting at Stjernsund, Northern Norway. Marine Geology 282, 5-12.

Salzmann, M.R., 2003. Late Paleozoic Ice Age: oceanic gateway or $\mathrm{pCO}_{2}$. Geology 31 , 151-154.

Sandberg, P.A., 1983. An oscillating trend in Phanerozoic non-skeletal carbonate mineralogy. Nature 305, 19-22.

Scheibner, C., Speijer, R.P., 2008. Late Paleocene-early Eocene Tethyan carbonate platform evolution - a response to long- and short-term paleoclimatic change. Earth-Science Reviews 90, 71-102.

Schlager, W., 2003. Benthic carbonate factories of the Phanerozoic. International Journal of Earth Sciences 92, 445-464.

Schlanger, S.O., Jenkyns, C., 1976. Cretaceous oceanic anoxic events: causes and consequences. Geologie en Mijnbouw 55, 179-184.

Schmid, D.U., Leinfelder, R.R., Nose, M., 2001. Growth dynamics and ecology of Upper Jurassic mounds, with comparisons to Mid-Palaeozoic mounds. Sedimentary Geology $145,343-376$.

Schopf, J.W., 1999. Cradle of life. The Discovery of Earth's Earliest FossilsPrinceton University Press 367.

Schröder, S., Adams, E.W., Grotzinger, J.P., McCormick, D.S., Amthor, J.E., Al-Hashimi, R., Al-Jaida, O., Al-Siyabi, H., Smith, D.W., Wood, R., 2001. Fabrics and genesis of microbial reefs in the terminal Neoproterozoic Nama Group (Central Namibia). GSA Annual Meeting, Paper No. 107-0.

Schubert, J.K., Bottjer, D.J., 1992. Early Triassic stromatolites as post-mass extinction disaster forms. Geology 20, 883-886.

Sears, S.O., Lucia, 1979. Reef-growth model for Silurian pinnacle reefs, northern Michigan reef trend. Geology 7, 299-302

Snedden, J.W., Liu, C., 2010. A compilation of Phanerozoic sea-level change, coastal onlaps and recommended sequence designations. AAPG Search and Discovery (Article \#40594).

Sorby, H.C., 1858. On the microscopical structure of crystals, indicating the origin of minerals and rocks. Quaterly Journal of the Geological Society of London 14 (1), 453-500.

Stanley Jr., G.D., 2001. The history and sedimentology of ancient reef systems. Topics in Geobiology, 17. Kluwer Academic/Plenum Publishers, p. 458.

Stanley, S.M., Hardie, L.A., 1998. Secular oscillations in the carbonate mineralogy of reefbuilding and sedimentproducing organisms driven by tectonically forced shifts in seawater chemistry. Palaeogeography, Palaeoclimatology, Palaeoecology 144, 3-19.

Stanton, R.J., Jeffery, D.L., Guillemette, R.N., 2000. Oxygen minimum zone and internal waves as potential controls on location and growth of Waulsortian mounds (Mississippian, Sacramento Mountains, New Mexico). Facies 42, 161-176.
Stanton, R.J., Jeffery, D.L., Wayne, M.A., 2002. Early Mississippian climate based on oxygen isotope compositions of brachiopods, Alamogordo Member of the Lake Valley Formation, south-central New Mexico. Geological Society of America Bulletin 114 (1), 4-11.

Stemmerik, L., 1997. Permian (Artinskian-Kazanian) cool-water carbonates in north Greenland, Svalbard and the western Barents Sea. In: James, N.P., Clarke, J. (Eds.), Cool Water Carbonates. SEPM Special Publication, 56, pp. 349-364.

Stetson, T.R., Squires, D.F., Pratt, R.M., 1962. Coral Banks Occurring in Deep Water on the Blake Plateau. American Museum Novitates 1-39 (no. 2114).

Stramma, L., Schott, F., 1999. The mean flow field of the tropical Atlantic Ocean. Deep Sea Research Part II: Topical Studies in Oceanography 46 (1-2), 279-303.

Surlyk, F., 1997. A cool-water carbonate ramp with bryozoans mounds. Late CretaceousDanian of the Danish Basin. In: James, N.P., Clarke, J. (Eds.), Cool Water Carbonates. SEPM Special Publication, 56, pp. 293-307.

Teichert, C., 1958. Cold and deep-water coral banks. American Association of Petroleum Geologists 42, 1062-1082.

Templer, S.P., Wehrmann, L.M., Zhang, Y., Vasconcelos, C., McKenzie, J.A., 2011. Microbial community composition and biogeochemical processes in cold-water coral carbonate mounds in the Gulf of Cadiz, on the Moroccan margin. Marine Geology $282,138-148$.

Thibodeaux, L.J., Boyle, J.D., 1987. Bedform-generated convective transport in bottom sediment. Nature 325, 341-343.

Thierens, M. Titschack, J., Dorschel, B. Huvenne, V.A.I, Wheeler, A.J., Stuut, J.-B. O'Donnell, R., 2010. The $2.6 \mathrm{Ma}$ depositional sequence from the Challenger coldwater coral carbonate mound (IODP Exp. 307): sediment contributors and hydrodynamic palaeo-environments. Marine Geology 271, 260-277.

Thierens, M., Pirlet, H., Colin, C., Latruwe, K., Vanhaecke, F., Lee, J.R., Stuut, J.-B., Titschack, J. Huvenne, V.A.I., Dorschel, B., Wheeler, A.J., Henriet, J.-P., 2012. Ice-rafting from the British-Irish ice sheet since the earliest Pleistocene (2.6 million years ago): implications for long-term mid-latitudinal ice-sheet growth in the North Atlantic region. Quaternary Science Reviews 44, 229-240.

UNESCO, 2008. Operational Guidelines for the Implementation of the World Heritage Convention. 173.

Vail, P.R., Mitchum, R.M., Thompson, S., 1977. Seismic stratigraphie and global changes of sea level, Part 4: Global cycles of relative changes of sea level. AAPG Memoir 26, 83-97.

Van Andel, T.J., 1985. New Views on an Old Planet. Cambridge University Press 458.

Van Raaphorst, W., Malschaert, H., Van Haren, H., Boer, W., Brummer, G.J., 2001. Cross-slope zonation of erosion and deposition in the Faeroe-Shetland Channel, North Atlantic Ocean. Deep Sea Research Part I - Oceanographic Research Papers 48, 567-591.

Van Rensbergen, P. Depreiter, D. Pannemans, B., Moerkerke, G., Van Rooij, D., Marset, B. Akhmanov, G., Blinova, V., Ivanov, M., Rachidi, M., Magalhaes, V., Pinheiro, L., Cunha, M., Henriet, J.P., 2005. The El Arraiche mud volcano field at the Moroccan Atlantic slope, Gulf of Cadiz. Marine Geology 219, 1-17.

Van Rensbergen, P., Rabaute, A., Colpaert, A., St. Ghislain, T., Mathijs, M., Bruggeman, A, 2007. Fluid migration and fluid seepage in the Connemara Field, Porcupine Basin interpreted from industrial 3D seismic and well data combined with high-resolution site survey data. International Journal of Earth Sciences 96, 185-197.

Van Rooij, D., De Mol, B., Huvenne, V., Ivanov, M., Henriet, J.-P., 2003. Seismic evidence of current-controlled sedimentation in the Belgica Mound province, upper Porcupine slope, southwest of Ireland. Marine Geology 195, 31-53.

Van Rooij, D., Huvenne, V.A.I., Blamart, D., Henriet, J.P., Wheeler, A., de Haas, H., 2009. The Enya mounds: a lost mound-drift competition. International Journal of Earth Sciences 98, 849-863.

Van Rooij, D., Blamart, D., De Mol, L., Mienis, F., Pirlet, H., Wehrmann, L.M., Barbieri, R., Maignien, L., Templer, S.P., de Haas, H., Hebbeln, D., Frank, N., Larmagnat, S., Stadnitskaia, A., Stivaletta, N., van Weering, T., Zhang, Y., Hamoumi, N., Cnudde, V., Duyck, P., Henriet, J.-P., the The MiCROSYSTEMS MD 169 shipboard part, 2011. Cold-water coral mounds on the Pen Duick Escarpment, Gulf of Cadiz: the MiCROSYSTEMS project approach. Marine Geology 282, 102-117.

Vennin, E., Aretz, M., Boulvain, F., Munnecke, A. (Eds.), 2007. Facies from Palaeozoic reefs and bioaccumulations, 195. Mémoires du Muséum National d'Histoire Naturelle, p. 341.

Viana, A.R., 1994. Deep-water coral mounds along the southeastern Brazilian continental slope. 14th International Sedimentological Congress, Recife, Abstract. International Association of Sedimentologists, p. 3 (D86).

Viana, A.R., Faugères, J.C., Kowsmann, R.O., Lima, J.A.M., Caddah, L.F.G., Rizzo, J.G., 1998. Hydrology, morphology and sedimentology of the Campos continental margin, offshore Brazil. Sedimentary Geology 115 (1-4), 133-157.

Wahlmann, G.P., 2002. Upper Carboniferous-Lower Permian (Bashkirian-Kungurian) mounds and reefs. In: Kiessling, W., Flügel, E., Golonka, J. (Eds.), Phanerozoic Reef Patterns. SEPM Special Publication, 72, pp. 271-338.

Webb, G.E., 2002. Latest Devonian and early Carboniferous reefs: depressed reef building after the middle Paleozoic collapse. In: Kiessling, W., Flügel, E., Golonka, J. (Eds.), Phanerozoic Reef Patterns. SEPM Special Publication, 72, pp. 239-269.

Wehrmann, L.M., Templer, S.P., Brunner, B., Bernasconi, S.M., Maignien, L., Ferdelman, T.G., 2011. The imprint of methane seepage on the geochemical record and early diagenetic processes in cold-water coral mounds on Pen Duick Escarpment, Gulf of Cadiz. Marine Geology 282, 118-137.

Wendt, J., Kaufmann, B., Belka, Z., 2001. An exhumed Palaeozoic underwater scenery: the Visean mud mounds of the eastern Anti-Atlas (Morocco). Sedimentary Geology 145, 215-233.

Wheeler, A.J., Beyer, A., Freiwald, A., de Haas, H., Huvenne, V.A.I., Kozachenko, M., Olu-Le Roy, K., Opderbecke, J., 2007. Morphology and environment of colwater 
coral carbonate mounds on the NW European margin. International Journal of Earth Sciences 96, 37-56.

Wheeler, A., Kozachenko, M., Masson, D.G., Huvenne, V.A.I., 2008. Influence of benthic sediment transport on cold-water coral bank morphology and growth: the example of the Darwin Mounds, north-east Atlantic. Sedimentology 55 (6), 1875-1887.

Wheeler, A.J., Kozachenko, M., Henry, L.-A., Foubert, A., de Haas, H., Huvenne, V.A.I., Masson, D.G., Olu, K., 2011. The Moira Mounds, small cold-water coral banks in the Porcupine Seabight, NE Atlantic: part A-an early stage growth phase for future coral carbonate mounds? Marine Geology 282, 53-64.

White, M., 2007. Benthic dynamics at the carbonate mound regions of the Porcupine Sea Bight continental margin. International Journal of Earth Sciences 97, 1-9.

Wienberg, C., Frank, N., Mertens, K.N., Stuut, J.-B., Marchant, M., Fietzke, J., Mienis, F., Hebbeln, D., 2010. Glacial cold-water coral growth in the Gulf of Cádiz: implications of increased palaeo-productivity. Earth and Planetary Science Letters 298, 405-416.
Wilson, J.L., 1975. Carbonate facies in geologic history. Springer Verlag, p. 471.

Wilson, E.O., 2012. The Social Conquest of the Earth. Liveright Publishing Corporation, New York 331.

Wilson, M.FJ. O'Connell, B., Brown, C., Guinan, J.C. Grehan, A.J. 2007. Multiscale terrain analysis of multibeam bathymetry data for habitat mapping on the continental slope. Marine Geodesy 30, 3-35.

Wisshak, M., Tapanila, L. (Eds.), 2008. Current Developments in Bioerosion. Erlangen Earth Conferences Series, Springer-Verlag, Berlin Heidelberg, p. 499.

Wood, R., 1999. Reef Evolution. Oxford University Press, Oxford, New York 414.

Wood, R., 2001. Are reefs and mud mounds really so different? Sedimentary Geology 145 $161-171$.

Zhang, Y., Henriet, J.P., Burssens, J., Boon, N., 2010. Stimulation of in vitro anaerobic oxidation of methane rate in a continuous high-pressure bioreactor. Bioresource Technology $101,3132-3138$ 